\title{
Dubrovački vodovod u XIX. i XX. stoljeću
}

\author{
IRENA IPŠIĆ \\ Sveučilište u Dubrovniku \\ Dubrovnik, Hrvatska \\ irena.ipsic@unidu.hr
}

U radu se prati razvoj dubrovačkoga vodovoda tijekom XIX. i XX. stoljeća, čija je okosnica (sve do sredine XX. stoljeća) bio vodoopskrbni gravitacijski sustav izgrađen u XV. stoljeću. Na temelju dosadašnjih saznanja, arhivskih dokumenata, starih novinskih napisa te dokumentacije iz pismohrane današnje gradske tvrtke „Vodovod Dubrovnik” prate se rekonstrukcije i popravci dotrajaloga vodovodnoga kanala i popratnih objekata, izgradnja i održavanje gradskih fontana, provođenje vodoopskrbne infrastrukturne mreže prema privatnim objektima te u konačnici projekt izgradnje cjelovitoga suvremenoga vodoopskrbnog sustava polovinom XX. stoljeća, kojim se i danas vodom napaja gradsko područje.

Ključne riječi: Dubrovnik; vodovod; gravitacijski kanal; fontana; XIX. i XX. stoljeće

\section{Uvod}

Povijest dubrovačkoga vodovoda prati se od 1437. godine i izgradnje najvažnijega infrastrukturnog projekta Dubrovačke Republike, ${ }^{1}$ kojim je voda s izvora u Šumetu (udaljenom 11,7 km) gravitacijskim kanalom dovedena unu-

\footnotetext{
1 Početkom XV. stoljeća unutar gradskih zidina živjelo je oko 6000 stanovnika (KRIVOŠIĆ, Stanovništvo Dubrovnika, 18). To je razdoblje početka većih građevinskih radova u Dubrovniku. Ruše se dijelovi starih i širi obuhvat novih zidina, grade se brojne kule (Lovrijenac, Minčeta, Revelin i dr.), uređuje gradska luka, proširuju žitnica i arsenal, grade tri zvonika (gradski te franjevački i dominikanski), popločava grad, a uvodi se i kanalizacija. Tada se snažnije počinje razvijati suknarski obrt, koji je za proizvodnju trebao znatnije količine vode (ROLLER, Dubrovački zanati u XV. i XVI. stoljeću, 1, 6, 113, 121; ŽILE, „Srednjovjekovna kanalizacija grada Dubrovnika”, 437-449). Zbog svega toga dotadašnji način opskrbe vodom (pomoću bunara te privatnih i javnih cisterni) nije više bio dostatan i sve se više osjećala nestašica (BERITIĆ, „Du-
} 
tar gradskih zidina, ${ }^{2}$ a na čijoj je izgradnji angažiran Onofrio di Giordano, rodom iz Cave u blizini Napulja. ${ }^{3}$ Za potrebe vodoopskrbe u urbanoj sredini tada su izgrađene i najvažnije gradske fontane - Velika i Mala Onofrijeva fontana. ${ }^{4}$ U blizini Male fontane poslije je izgrađena i židovska fontana za opskrbu dubrovačkih Židova, koja se vjerojatno prije potresa 1667. nalazila i u getu. ${ }^{5}$ Voda iz vodovodnoga kanala provedena je i na manju fontanu u Kneževu dvoru (sagrađenu 1445.), na fontanu u gradskoj luci (sagrađenu 1475.) te na fontanu koja je izgrađena na Pločama, prostoru nekadašnjega sajmišta i mjestu na kojem su se okupljale turske karavane. ${ }^{6}$ Prostor oko Velike fontane postao je centralna gradska lokacija, ${ }^{7}$ mjesto okupljanja i sastajanja. Tu su se susretali pripadnici

brovački vodovod”, 100; SEFEROVIĆ, STOJAN, „Čudo vode”, 98-99; BELAMARIĆ, „Urbanistički aspekti prve dubrovačke industrije u 15. stoljeću", 341-372).

2 Gradnja vodovodnoga kanala pomno je planirana. Najprije je određeno izvorište, a kao idealno nametnuo se izvor rijeke Omble. Međutim, to se nije moglo realizirati zbog tadašnjih tehnoloških mogućnosti i činjenice da se izvor nalazi neposredno uz morsku obalu i da vodu iz toga izvora slobodnim padom nije moguće dovesti do grada. Zbog visinske razlike kao najbolje rješenje nametnulo se izvorište Vrelo, u blizini sela Šumet, smješteno na koti od $109 \mathrm{~m}$ nadmorske visine. $S$ toga (iako poprilično udaljenog) izvora voda je mogla slobodnim padom dotjecati sve do grada prateći konfiguraciju terena. Više o izgradnji ranorenesansnoga vodovoda u Dubrovniku vidi u: BERITIĆ, „Dubrovački vodovod”, 99-116; DIVERSIS, Opis slavnoga grada Dubrovnika, 59-60; SEFEROVIĆ, STOJAN, „Čudo vode”, 95-137; MAJER JURIŠIĆ, ŠURINA, Velika Onofrijeva fontana u Dubrovniku, 8-21.

3 Onofrio je u Dubrovniku boravio od 1436. do 1443. godine. Bio je jedini stranac kojem je Dubrovačka Republika podigla spomen-ploču i najbolje plaćeni namještenik Republike u XV. stoljeću. Poznat je kao graditelj vodovoda, dviju fontana, Kneževa dvora i utvrda. Više u: DIVERSIS, Opis slavnoga grada Dubrovnika, 59-60; SEFEROVIĆ, STOJAN, „Čudo vode”, 102-103; GRUIĆ, „Onofrio di Giordano della Cava”, 9-50; MAJER JURIŠIĆ, ŠURINA, Velika Onofrijeva fontana u Dubrovniku, 9. Izvorni tekst ugovora sklopljenog između investitora (Dubrovačke Republike) i izvođača radova (poduzetnika Andreuzza de Bulbita i projektanta i glavnoga inženjera u izvedbi Onofrija di Giordana) transkribirali su i objavili još 1940. Risto Jeremić i Jorjo Tadić, a prijevod ugovora dostupan je u radu Relje Seferovića i Mare Stojan (HR-DADU, Acta Consilii Maioris, sv. 5, f. 79v-81v; JEREMIĆ, TADIĆ, Prilozi za istoriju zdravstvene kulture, sv. III, 11-14; više u: SEFEROVIĆ, STOJAN, „Čudo vode”, 103-104).

4 Najprije se započelo s izgradnjom Velike fontane, a projekt njezine izgradnje također je povjeren Onofriju. Ugovor s Onofrijem sklopljen je 7. veljače 1438. godine (HR-DADU, Diversa Cancellariae, sv. 52, f. 70-72; JEREMIĆ, TADIĆ, Prilozi za istoriju zdravstvene kulture, sv. III, 1518; NOVAK KLEMENČIČ, „Dubrovniška Velika fontana”, 83-86; MAJER JURIŠIĆ, ŠURINA, Velika Onofrijeva fontana u Dubrovniku, 74-75). Ugovor o gradnji Male fontane potpisan je u listopadu 1440. godine (JEREMIĆ, TADIĆ, Prilozi za istoriju zdravstvene kulture, sv. III, 18-19; BERITIĆ, „Dubrovački vodovod”, 101; SEFEROVIĆ, STOJAN, „Čudo vode”, 123-124).

5 Prema predaji, dijelovi židovske fontane premješteni su na Pile. Fontana se na Pilama nalazi i danas. Više u: MIOVIĆ, Židovski geto u Dubrovačkoj Republici, 88-89.

6 BAZALA, Pregled povijesti zdravstvene kulture, 17-18; BERITIĆ, „Dubrovački vodovod”, 105-106. O terminu fontana i njezinu značenju u oblikovanju gradskoga prostora više u: HORVAT, „Fontana i njezino mjesto", 341-350.

7 Fontanama, bunarima i cisternama ukrašeni su javni i privatni prostori grada, a voda je često korištena kao arhitektonski i urbani oblikovni element. Više u: BELAMARIĆ, „Fontane”, 186; FABIJANEC, „Uloga vode”, 9-43; SINDIK, BRIŠKI, „Različitost percepcije simboličkog značenja vode", 453-468. Mjesta na kojima su se gradile fontane sugeriraju elitne dijelove grada, u kojima živi najveći udio pripadnika povlaštenoga staleža. Nakon izgradnje dubrovačkoga 
različitih društvenih slojeva i zanimanja, domaći ljudi i stranci. ${ }^{8}$ I područje oko Male fontane bilo je važno gradsko čvorište. Kraj nje se pralo rublje, a tu je bila i mala kamenica uzidana u pločnik iz koje su se vode mogli napiti i gradski psi. U blizini se nalazila i gradska luža, gdje se sastajala vlastela, stranci i prolaznici. S vanjske strane luže obično se prodavalo povrće jer se tu nalazila gradska tržnica, pa je blizina izvorske vode upravo na tome mjestu bila prava blagodat. Oko nje su se pored trgovaca ili prodavačica svakodnevno okupljale domaćice i sluškinje, gdje su točile vodu ili prale robu. ${ }^{9}$

Premda je odmah nakon izgradnje pokazao mnoge slabosti i nedostatnosti, zbog čega je često zahtijevao popravke i rekonstrukcije, ${ }^{10}$ gravitacijski vodovodni sustav iz XV. stoljeća bio je okosnica vodoopskrbe urbanoga gradskog prostora sve do druge polovine XX. stoljeća, kada se pristupilo izgradnji suvremenoga dubrovačkog vodovoda.

\section{Vodovod u XIX. stoljeću}

Politički prevrati s kraja XVIII. i početka XIX. stoljeća umnogome su ostavili trag na daljnji razvoj dubrovačkoga područja, ali i život u samome gradu. ${ }^{11}$ Tijekom francuskoga zauzimanja Dubrovnika stradao je i dubrovački vodovod. Sredinom lipnja 1806. presječen je vodovodni kanal u blizini izvora u Šumetu i grad je ostao bez glavnoga izvora vode. ${ }^{12}$ Vladala je velika nestašica,

gravitacijskog vodovoda, a slijedeći nova komunalna rješenja, elitni dio grada pomiče se nešto sjevernije, oko glavne ulice Place, koja je postala novo središte grada, a na čijim se krajnjim točkama s istočne i zapadne strane nalaze najvažnije gradske fontane. Vidi: IPŠIĆ, LAZAREVIĆ, „Water in the urban space of Dubrovnik”, 190-191.

8 Javna mjesta s vodom bila su važna čvorišta društvenoga života i gradske svakodnevice. Onamo se dolazilo osluhnuti bilo grada, saznati gradska šaputanja, dogovoriti poslovnu suradnju, obaviti posao i slično (MUMFORD, Grad u historiji, 297-298).

9 STOJAN, Vjerenice i nevjernice, 122; FISKOVIĆ, „Petar Martinov iz Milana”, 114-119; FISKOVIĆ, Reljef renesansnog Dubrovnika, 128-131. Stanovnici grada nisu po vodu dolazili isključivo na vanjske fontane, nego su svoje potrebe za vodom često zadovoljavali i na fontani u atriju Kneževa dvora (LONZA, „Svakodnevica Kneževa dvora”, 8).

10 O nadogradnjama i rekonstrukcijama Onofrijeva vodovoda tijekom stoljeća više u: JANEKOVIĆ RÖMER, „Extension of the Ragusan aqueduct”, 319-326; SEFEROVIĆ, „Radovi na dubrovačkom vodovodu", 141-154.

11 Najveći prevrat i promjene dogodili su se 1808., nakon ukidanja višestoljetne samostalnosti Dubrovačke Republike. Ta tematika obrađena je u više znanstvenih radova, primjerice: VOJNOVIĆ, Pad Dubrovnika, passim; ĆOSIĆ, Dubrovnik nakon pada Republike, 33-68; ČUČIĆ, Posljednja kriza Dubrovačke Republike, 87-140.

12 BERITIĆ, „Dubrovački vodovod”, 108. Problem vodoopskrbe ističe suvremenik F. M. Appendini u svojim zapisima koje je vodio za vrijeme opsade. Pored opisa nestašice i gužvi koje su se stvarale na mjestima za vodu ističe i događaj kada je bomba pala „[...] na mjesto gdje se davala voda i ubila četiri, a ranila devet osoba”. Više u: APPENDINI, „Ratovanje oko Dubrovnika godine 1806”. Presijecanje vodovodnoga kanala od rusko-crnogorske vojske za vrijeme opsade 
a zbog ljetnih vrućina stanovništvu su prijetile i zaraze. ${ }^{13}$ Zauzevši Dubrovnik, francuska uprava iskoristila je i veliki broj crkava i samostana za vojne potrebe i u njima smjestila skladišta i vojarne. Tada su samostan i crkva sv. Klare pretvoreni u vojni arsenal, a neposredno uz Veliku fontanu bio je prostor za konjušnicu i skladište streljiva. Podizanjem visokih ogradnih zidova oko vanjskoga prostora samostana sve do Velike fontane ograđen je južni dio fontane, koji više nije bio dostupan stanovništvu, a sama fontana i otvoreni prostor oko nje velikim su dijelom izolirani i zatvoreni. ${ }^{14}$ Da je stanje u vodoopskrbi tih godina bilo iznimno loše svjedoči i molba upućena intendantu Dubrovačke pokrajine Félixu Baillardelu de Lareintyju kojom se od njega traži naredba o zabrani pranja odjeće u kamenim bazenima javnih fontana, pa tako i Velike fontane, pod prijetnjom kazne. Razlog je vjerojatno vrlo loše stanje javnih fontana, ali i oskudna količina vode koja do njih dotiče. ${ }^{15}$

Godine 1811. u službu civilnoga inženjera za dubrovačko područje došao je arhitekt i inženjer Lorenzo Vitelleschi, koji je na toj funkciji ostao i nakon uspostave austrijske vlasti, odnosno sve do 1831. godine. Upravo je on 1826. radio na obnovi i poboljšanju vodoopskrbe grada, kada je vodovodni kanal povezan s tri nova izvora. Vjerojatno posao nije izveden kako treba jer ga je liječnik i književnik Luka Stulli u jednoj svojoj pjesmi prozvao zbog loše obavljena posla. ${ }^{16}$ Vitelleschi je u svojem djelu Notizie storiche e statistiche del circolo di Ragusa iz 1827. donio popis fontana na užem gradskom području u prvoj polovini XIX. stoljeća. Uz svaki opis priložena je i skica/akvarel fontane. Najprije spominje „Školjkastu fontanu na Pilama” (Fontana a Vasca alle Pile) te ju opisuje: „[...] iz središta osmerokutne školjke izvire dosta visoko jedan mlaz, koji

Dubrovnika 1806. spominje se u tjedniku Narodna svijest više od 130 godina poslije (Narodna svijest /Dubrovnik/, 22. 5. 1940., 21).

13 Policijski komesar Angelo Frezza, kojega je francuska uprava zadužila za vodovod, cisterne i fontane, u nekoliko je navrata tražio sredstva za neophodne popravke na vodovodnom kanalu, no učinilo se vrlo malo (BERITIĆ, „Dubrovački vodovod”, 108; VUKOVIĆ, „Preobrazba Dubrovnika početkom 19. stoljeća”, 40).

14 MAJER JURIŠIĆ, ŠURINA, Velika Onofrijeva fontana u Dubrovniku, 28.

15 Dana 17. kolovoza 1813. Baldassare Trojani, član gradske uprave u Dubrovniku, obavještava pokrajinskoga intendanta de Lareintyja da je vodovodni kanal kojim se napaja Velika fontana razbijen i da u njoj više nema ni kapi vode. Zato traži da se razmotri na koji će se način i na čiji trošak kanal popraviti (HR-DADU, Acta Gallica, kut. 126, Tit. II., Rub. 10). Također vidi: MAJER JURIŠIĆ, ŚURINA, Velika Onofrijeva fontana u Dubrovniku, 28-29. Vodovodni je kanal i tijekom smjene francuske vlasti imao ključnu ulogu u strategiji ratovanja. U siječnju 1814. Englezi su prekinuli dotok vode i neprekidnim napadima na grad natjerali Francuze na predaju (ĆOSIĆ, Dubrovnik nakon pada Republike, 107-108; VOJNOVIĆ, Pad Dubrovnika, sv. II, 189-193; BELAMARIĆ, „Urbanistički aspekti prve dubrovačke industrije u 15. stoljeću”, 355; SEFEROVIĆ, „Radovi na dubrovačkom vodovodu”, 149).

16 VITELLESCHI, Povijesne i statističke bilješke o Dubrovačkom okrugu, 119; VUKOVIĆ, „Vode, zdenci i fontane dubrovačkog kraja. I. dio”, 67-71; VUKOVIĆ, ANDROVIĆ, „Vode, zdenci i fontane dubrovačkog kraja. II. dio", 82-83. 
se prelijeva u bezbroj varijacija, a drugo na njoj nije vrijedno spomena.” Potom opisuje „Veliku natkrivenu fontanu” (Fontana grande coperta): „Smještena je blizu arsenala, osmerokutna, pokrivena prstenastim voltom. U sredini svake strane izbija voda iz raznih maskerona u veliki bazen. Svaka je strana ukrašena cilindričnim stupom sa životinjskim likom. Sada je ostala samo jedna figura s likom psa.” Slijede „Piramidalna fontana” (Fontana piramidale), koja je „[...] smještena blizu stražarske kuće i ima bazen s piramidalnom grupom [sic! ] iz koje izbija voda iz različitih mlazova”; „Nadsvođena fontana” (Fontana arcuata), koja se nalazi „[...] u dvorištu Kneževa dvora, a bazen je smješten ispod luka”; „Ugrađena fontana” (Fontana addosata), koja se zvala i Revelinova „[...] jer je naslonjena na njegove stube [...]”; „Druga ugrađena fontana” (Altra fontana addosata), koja se prema Vitelleschijevoj zamisli trebala graditi na trgu Mrtvo zvono, te „Usamljena fontana” (Fontana isolata), koja se nalazi „[...] unutar zakloništa na Pločama za turske karavane, a njezin veliki bazen služi i kao podloga gradnji urešenoj stupovima, iz središta koje izbija voda iz jednog maskerona". ${ }^{7}$

Konkretnija promišljanja o poboljšanju vodoopskrbe intenzivirala su se početkom XIX. stoljeća nakon što je regulirano vlasništvo i pitanje obveze održavanja vodovodne infrastrukture. Zbog toga je 1836. izdan i Pravilnik o čuvanju i održavanju vodovoda. Na temelju njega saznaje se da su svi izvori, skupa s vodovima i kanalima, vlasništvo općine Dubrovnik. Spominju se izvori Bota, Orahovac, Bračevica, Vrelo, Podvrelo, Vrijesna glavica i Marčevo. ${ }^{18}$ Pravilnik nabraja i sve gradske fontane: u Gružu kod dominikanskoga samostana, na Brsaljama, Veliku Onofrijevu fontanu, Malu Onofrijevu fontanu, fontanu kod gata Ribarnice, na Mrtvom zvonu, na Revelinu, u Dvoru i na Pločama (Međed). Tada je ukupno popisano devet fontana. Pravilnik je propisivao i kazne za one koji bi zloupotrebljavali vodovod, a globe za prekršitelje iznosile su od 1 do 50 forinti ili od jednoga do trideset dana zatvora. Bilo je zabranjeno vađenje kamenja ili zemlje na udaljenosti od 70 hvati (oko $132 \mathrm{~m}$ ) od izvora, a miniranje hridina na udaljenosti od 200 hvati (oko $380 \mathrm{~m}$ ). Na udaljenosti od 5 hvati (oko $9 \mathrm{~m}$ ) bila je zabranjena sadnja stabala, a za sadnju na prostoru od 5 do 10 hvati trebala je dozvola Općine. ${ }^{19}$

Usprkos većoj brizi za održavanje i zaštitu cijeloga vodoopskrbnog sustava, i dalje postoje veliki problemi oko osiguravanja dostatne količine vode u urbanoj jezgri. ${ }^{20}$ Općina ih, u okviru ograničenih financijskih mogućnosti, nastoji

\footnotetext{
VITELLESCHI, Povijesne i statističke bilješke o Dubrovačkom okrugu, 90-93.

Odredbe Pravilnika preuzete su iz: BERITIĆ, „Dubrovački vodovod”, 108-109.

BERITIĆ, „Dubrovački vodovod”, 108-109.

Za razliku od izvangradskoga i seoskoga područja, gdje početkom XIX. stoljeća ubrzano raste broj stanovnika, u samoj urbanoj središnjici dolazi do stagnacije, a broj stanovništva čak
} 
riješiti popravcima, rekonstrukcijama, preuređenjima i ojačanjima postojećih sustava. Međutim, kada se u drugoj polovini XIX. stoljeća voda počela provoditi u pojedine institucije, poput novoizgrađene bolnice ${ }^{21}$ ili hotela Imperijal ${ }^{22}$, te u privatne stanove i kuće, problem vodoopskrbe postaje još veći, a nedostatak vode još izraženiji. ${ }^{23} \mathrm{U}$ takvoj situaciji više se nije moglo pribjegavati polovičnim i kratkoročno učinkovitim rješenjima, nego je trebalo započeti s promišljanjem o izradi novoga vodoopskrbnog sustava koji bi se koristio vodnim bogatstvom izvora rijeke Omble, najbogatijega izvora pitke vode na dubrovačkom području. Prvi projekt koji je predviđao postavljanje naprave za tlačenje vode iz izvora Omble u stari vodovod izradio je 1887. inženjer Karlo Bauda. ${ }^{24}$ Prema njegovu projektu, trebala se postaviti pumpa na vodeni pogon koja bi kroz cjevovod promjera $100 \mathrm{~mm}$ dnevno davala $480 \mathrm{~m}^{3}$ vode. Potrebnu pumpu i cjevovod ponudio se instalirati tadašnji vlasnik mlinova na Ombli uz uvjet da mu Općina plaća godišnji najam od 2.000 forinti tijekom 29 godina. Kako je za Općinu taj iznos bio previsok, zatražili su ponudu od inženjera Brüchnera iz Beča za parnu pumpu. Međutim, cijeli je plan propao jer je nastao spor oko vlasništva nad izvorom Omble. Vlasnik mlinova smatrao je da je voda s izvora u njegovu vlasništvu. ${ }^{25}$

je i u laganom padu. Tako se 1807. godine bilježi 6514, a 1847. godine 6154 stanovnika (ĆOSIĆ, Dubrovnik nakon pada Republike, 199-203).

21 O izgradnji dubrovačke bolnice, dovršene 1888., više u: PERIĆ, „Organizacija i djelovanje pokrajinske bolnice u Dubrovniku”, 175-222; PIPLOVIĆ, „Početak gradnje modernih bolnica u Dalmaciji”, 322-323; PERIĆ, „Organizacija zdravstvene službe”, 187-204.

22 O izgradnji Grand hotela Imperijal više u: PERIĆ, Razvitak turizma u Dubrovniku i okolici, 54-65; AHMETOVIĆ, Dubrovački kurioziteti iz dva minula tisućljeća, 276-281.

23 Broj stanovnika na gradskom području tijekom druge polovine XIX. stoljeća znatnije se povećava - od 7738, koliko ih ima 1857., na 11 584, koliko ih ima 1900. godine (KORENČIĆ, Naselja i stanovništvo SR Hrvatske, 219).

24 Karlo Bauda jedan je od najistaknutijih arhitekata koji su djelovali u Hrvatskoj krajem XIX. i početkom XX. stoljeća. Među ostalim projektima, 1888. radio je i na izgradnji nove bolnice u Dubrovniku. Više u: JURIĆ, „Arhitekt Martin Pilar”, 152-167; RADOVIĆ MAHEČIĆ, „Sekvenca secesije - arhitekt Lav Kalda”, 241-264.

25 BERITIĆ, „Dubrovački vodovod”, 109. Pitanje vlasništva nad vodnim bogatstvom rijeka u to vrijeme bilo je regulirano austrijskim Općim građanskim zakonikom. Njegov paragraf 287., naslovljen „Stvari ničije, javno dobro i državna imovina”, među ostalim jasno definira pravni status rijeka: „Stvari ničije zovu se one, koje svi državljani mogu prisvojiti. One stvari pak, koje su im dozvoljene samo na porabu kao: ceste, velike i male rijeke, luke i obale morske zovu se općeno ili javno dobro." Tom odredbom rijeke se stavljaju u poseban pravni režim nad kojim nije moguće pravo vlasništva, nego samo pravo korištenja. Zemaljski sabor Kraljevine Dalmacije donio je 1873. Zakon za kraljevinu Dalmaciju o uporabi, odvođenju i obrani od voda izuzev mora, koji je stupio na snagu 15. svibnja 1873., a preuzeo je odredbe austrijskoga Državnog zakona o vodnom pravu. U konačnici je i Sabor Hrvatske, Slavonije i Dalmacije 31. prosinca 1891. donio Zakon o vodnom pravu, u kojem je na sveobuhvatan način regulirana problematika vodnoga prava. Više u: VOJKOVIĆ, ŠTAMBUK-ŠUNJIĆ, „Dva hrvatska zakona o pravnom statusu voda", 201-204. 
Godine 1888. braća Federico i Emilio Camelli izradila su novi detaljni elaborat o vodovodu, iz kojega se doznaju mnoge pojedinosti o tadašnjem stanju dubrovačkoga vodovoda. U to vrijeme vodovod od izvora Vrelo do grada nije uopće imao rezervoar osim onoga na samome izvoru. Cjevovodi još nisu bili postavljeni, voda je do gradskih fontana i dalje tekla starim kamenim kanalima i cijevima, a dionice kanala (primjerice od izvora Bota prema izvoru Vrelo) nisu bile u funkciji. ${ }^{26}$

Prema mjerenjima koja je proveo inženjer Bauda sredinom rujna 1886. godine (a koja su braća Camelli navela u svojem elaboratu), izvori koji su napajali stari vodovod dnevno su davali 284,64 $\mathrm{m}^{3}$ vode (Vrelo 266,4 $\mathrm{m}^{3}$, Podvrelo 14,4 $\mathrm{m}^{3}$, Vrijesna glavica $2,4 \mathrm{~m}^{3}$ i Marčevo $\left.1,44 \mathrm{~m}^{3}\right) .{ }^{27}$

Braća Camelli predložila su izgradnju novoga kanala vodovoda koji bi s Onofrijevim vodovodom spojio još dva dosta jaka, a napuštena izvora: Orahovac, s kapacitetom od 17,42 $\mathrm{m}^{3}$, i Bračevicu, s kapacitetom od 55,73 $\mathrm{m}^{3}$ vode dnevno. Oni su se protivili Baudinu prijedlogu prema kojem bi se obnovila napuštena trasa od Bote do Vrela. Isticali su da je na tom dijelu zemljište klizavo i porozno te kao takvo nepodesno za vodovodni kanal. Izvor Bota u to je vrijeme davao $21,6 \mathrm{~m}^{3}$ vode dnevno, no bez obzira na to, iskustvo prethodnih razdoblja jasno pokazuje da je ta dionica vodovoda (od Bote do Vrela) bila potpuno neučinkovita zbog klizanja zemljišta, što je zahtijevalo česte i skupe popravke te je upravo zato i napuštena. Trasa novoga kanala od Orahovca do Vrela protezala bi se po čvrstom zemljištu iznad stare i napuštene trase, a priključenjem izvora Orahovac i Bračevica ukupni dnevni priljev vode ljeti bi iznosio $355 \mathrm{~m}^{3}$. Braća Camelli u sklopu svojega projekta predložila su i izgrad-

\footnotetext{
26 Iako je Onofrijev vodovod gradskom urbanom središtu donio veliko poboljšanje u vodoopskrbi, već nekoliko godina nakon njegove izgradnje počinje se preispitivati mogućnost njegova poboljšanja i proširenja priključenjem dodatnih izvora na vodovodni kanal. Na vodovod je najprije priključen izvor Bota ili Knežica, udaljen 1,3 km sjevernije od izvora Vrelo, a nešto kasnije još dva izvora, Orahovac i Račevica, koja su također bila pogodna jer su i ljeti davala određenu količinu vode i ne bi presušila. Međutim, nova produžena trasa vodovoda odmah nakon izgradnje počela je pokazivati velike nedostatke. Izgrađena je na klizavu terenu te je često propadala, što je zahtijevalo učestale popravke i nadogradnje. Popravci na novoizgrađenim trasama vodovodnoga kanala izvodili su se učestalo tijekom XVI. i XVII. stoljeća. Više u: HR-DADU, Acta Consilii Rogatorum, sv. 13, f. 262v-263v i sv. 26, f. 202-202v; JEREMIĆ, TADIĆ, Prilozi za istoriju zdravstvene kulture, sv. I, 44; JEREMIĆ, TADIĆ, Prilozi za istoriju zdravstvene kulture, sv. III, 24-26; BERITIĆ, „Dubrovački vodovod”, 102-104; SEFEROVIĆ, STOJAN, „Čudo vode”, 131-132; HR-DADU, Fabricae, sv. 1, f. 1-41; JANEKOVIĆ RÖMER, „Extension of the Ragusan aqueduct”, 319-326. Nakon što su tek u drugoj polovini XVI. stoljeća dobro izvedeni radovi na proširenju vodovodnoga kanala, grad se vodom napajao iz sljedećih izvora (u zagradi su stariji nazivi): Bota (Knežica, Potpod), Orahovac, Račevica (Vrasicica, Vuras, Vrčevo), Vrelo (Šumet, Slavica, Slavjan), Podvrelo (Unosilo), Vrijesna glavica (Vrijesni vrutak) i Marčevo. Cijela duljina vodovoda, i staroga i novoga, od izvora Bota do ulaska u grad tada je iznosila $13 \mathrm{~km}$ (BERITIĆ, „Dubrovački vodovod”, 105-106).

27 Podaci preuzeti iz: BERITIĆ, „Dubrovački vodovod”, 109.
} 
nju rezervoara na položaju Mlini od najmanje $500 \mathrm{~m}^{3}$ kapaciteta ili da se za rezervoare uredi Minčeta i još dvije do tri gradske kule koje bi mogle primiti oko $720 \mathrm{~m}^{3}$ vode. Predložili su i nagodbu s vlasnicima mlinova ili da Općina uspostavi parnu pumpu s vodovodnim cijevima. Budući da bi tlačenje vode s izvora Omble u stari vodovod bilo potrebno samo tijekom tri ljetna mjeseca, njihov je prijedlog bio da se za ta tri mjeseca vlasniku mlinova isplati 650 forinti, a ne 2.000, koliko je traženo za cjelogodišnji najam. Cjevovodi i pumpe na vodeni pogon stajali bi oko 20.000 forinti, a na parni pogon oko 24.000 forinti. ${ }^{28}$

U srpnju 1891. iz općinske blagajne odobreno je 17.674 forinte za pripajanje izvora Bračevica, Orahovac i Potpod u vodovodnu mrežu. Ipak, to nije realizirano jer je Zemaljski odbor u Zadru odbio prijedlog. Zamjerka projektu prvenstveno se odnosila na količinu vode. Smatralo se da se na taj način ne bi dobilo $134 \mathrm{~m}^{3}$ vode, nego samo $95 \mathrm{~m}^{3}$. Također, Zemaljski odbor kao prioritet je istaknuo popravak postojeće vodovodne infrastrukture. ${ }^{29}$

Radi poboljšanja vodoopskrbe i povećanja dotoka vode u grad bilo je neophodno u blizini izgraditi i nove rezervoare za vodu. Kako bi se u njima izgradili potrebni rezervoari, Općina je 1894. od Vojnoga erara zatražila da joj se ustupi Minčeta i tri kule. Vojna vlast pristala je ustupiti tri kule, ali ne i Minčetu, i to uz godišnji najam od 100 forinti. O tome je 12. veljače 1896. sklopljen ugovor, prema kojem se kule u najmu nisu smjele mijenjati izvana i morale su se održavati u ispravnom stanju. U najam su dane obje kule između vrata od Pila i Minčete te kula sv. Vida na Pelinama. ${ }^{30}$

Krajem XIX. stoljeća u gradu se počela osjećati još veća nestašica vode, i to ne samo tijekom sušnih ljetnih mjeseci nego je problema u vodoopskrbi bilo već od svibnja. To su bile jasne naznake da hitno treba riješiti gorući komunalni problem, pa je na kraju ipak prihvaćeno rješenje o zakupu parne pumpe, a sklopljen je i ugovor s vlasnikom mlinova u Rijeci, Vlahom Kisićem, za isporuku $960 \mathrm{~m}^{3}$ vode dnevno po cijeni od 3.000 forinti za šest mjeseci. Jedino u slučaju većih potreba voda se trebala isporučivati i tijekom zime. ${ }^{31}$ Realizacija toga projekta najavljena je krajem travnja 1897. i u tjedniku Crvena Hrvatska u članku „Za vodu”: „Brzo ćemo imati obilno vode ako općina sklopi pogodbu sa vlasnikom izvora na Rijeci gosp. Vlahom Kisićem, koji se obvezuje da će za 6000 fior. godišnje podignuti i baciti na gornji Kono 960.000 litara vode na

28 BERITIĆ, „Dubrovački vodovod”, 109-110.

29 PIPLOVIĆ, „Javne gradnje u Dubrovniku za austrijske uprave”, 334.

30 BERITIĆ, „Dubrovački vodovod”, 108, 110.

31 U tu je svrhu vlasnik mlinova osigurao dvije tlačne pumpe koje su tlačile vodu u stari kanal kroz tlačnu cijev promjera $125 \mathrm{~mm}$. Pogon tih pumpi bila je obična vodena snaga, a način funkcioniranja sličan onom koji pokreće mlinove. Više u: BERITIĆ, „Dubrovački vodovod”, 110-111. 
dan. Sa onijem što se sada iz starijeh vrela dobiva to bi došlo od prilike 131.5 litara vode na dan na svakog gragjanina, što je dovoljna količina." ${ }^{32}$

Pumpanje vode s izvora Omble službeno je počelo 30. rujna 1897. godine. ${ }^{33}$ Iako se time dobilo oko 1311 po stanovniku dnevno, ${ }^{34}$ ni to nije osiguralo potrebne količine vode koje su grad i gradsko stanovništvo u tom trenutku trebali. Tako je već 23. listopada 1897. u novinama objavljeno: „Svak se čudi, da iza kako g. Kišić baca silnu vodu na Kono, na našim fontanama isto nema vode, osobito na Luži gdje djevojke moraju toliko čekati, dok natoči onaj pisak vode što tamo curi. Razlog je tome taj što sva voda koja se baca na Kono, gubi se putem na više mjesta, a najviše povrh Čajkovice, gdje iz pukotina uprav potok teče, te je tako veoma malo u grad dolazi. Tako općina u ludo baca $20 \mathrm{f}$. na dan za vodu, bez ikakve koristi za grad, ako se Kono što prije ne načini." ${ }^{\prime 3}$ I u studenome 1897. u članku pod nazivom „Voda” u Crvenoj Hrvatskoj ističe se da vode u gradu gotovo da i nema, a govori se i o lošem održavanju Velike fontane: „U velikom bunaru one [fontane] kod Male Braće pijavica koliko ti drago, a Bog sam znade kad je očišćena bila. Istina čeka se uregjeni vodovod, ali dok ovaj dogje, još će mnogo vode proteći. Ne bi li se i ovo dalo popraviti?"36

Jedan od razloga nedostatka vode u gradu nakon stavljanja u pogon tlačnih pumpi zasigurno je i taj što se u to vrijeme voda počela provoditi prema pojedinim stambenim objektima, što je još više povećalo potrošnju. Kako tada nije postojala općinska vodovodna radionica, ni strategija postavljanja vodovodnih cijevi, voda se prema privatnim objektima provodila bez ikakva plana i sustavnoga nadzora. Radove su izvodili različiti privatni obrtnici, pa se često nije ni znalo kuda su cijevi postavljene. ${ }^{37} \mathrm{U}$ to je vrijeme i Uprava Blagoga djela

\footnotetext{
32 Crvena Hrvatska (Dubrovnik), 24. 4. 1897., 17.

33 PERIĆ, Razvitak turizma u Dubrovniku i okolici, 215 (bilj. 173). U časopisu Crvena Hrvatska o tom je događaju 2. listopada zapisano: „Pitanje vode, koje je toliko morilo Dubrovnik, riješeno je već. Prekojučer otvorio se novi kanal iz vrela Rijeke, kojom g. Kisić sa strojevima bacaće vodu u vodovod u tolikoj množini, da će nam je više i za najgorih suša biti dostatno. Tom prigodom nagioše se u Rijeci načelnik g. Gondola sa članovima vijeća i upraviteljstva, c. k. Kot. Poglavar Tončić i nekoliko drugih pozvanika. Iza blagoslova i prigodnih riječi koje izmijeniše posjednik izvora i načelnik Rijeke te načelnik Dubrovnika, udari ovaj bocom šampanjca po strojevima, na što se oni isti čas stave u gibanje i studena voda kroz jake željezne cijevi mlazne put Konala u visinu od kakovih 160 met. Stroj za dizanje vode vrlo je jak, tako da može u potrebi bacit na Kono 700 hl. na uru, ali po pogodbi bacaće ih redovito 400 hl., što je za Dubrovnik dosta i malo je gradova koji imaju razmjerno toliku količinu vode. Kad je puštena voda, oglase se na Konalu puške i maškuli, dočim je okolo bilo okićeno hrvatskim i inim trobojnicama [...].” (Crvena Hrvatska, 2. 10. 1897., 39).

34 PIPLOVIĆ, „Javne gradnje u Dubrovniku za austrijske uprave”, 334.

35 Crvena Hrvatska, 23. 10. 1897., 42.

36 MAJER JURIŠIĆ, ŠURINA, Velika Onofrijeva fontana u Dubrovniku, 27-28.

37 BERITIĆ, „Dubrovački vodovod”, 111.
} 
sagradila mali rezervoar za vodu na Pelinama i počela provoditi vodovodne instalacije za kuće koje su bile u njezinu vlasništvu. ${ }^{38}$

Tijekom cijeloga XIX. stoljeća briga o stanju Velike fontane, kao građevine od velikoga komunalnog značenja, ali i iznimne baštinske vrijednosti, nije bila odgovarajuća. ${ }^{39}$ Stručna konzervatorska briga o Velikoj fontani započinje tek 1894., kada je Josip Gelčić poslao dopis bečkom Carskom i kraljevskom središnjem povjerenstvu za istraživanje i održavanje građevinskih spomenika tražeći uklanjanje zidova oko Velike fontane koji su podigli Francuzi kada su samostan sv. Klare prilagođavali vojnim potrebama. Uslijedila je prepiska između Ministarstva kulture i obrazovanja i Središnje komisije, u kojoj je Ministarstvo zahtijevalo od Komisije vještačenje vezano uz njezino odzidavanje, tako da je do početka odzidavanja prošlo još desetak godina i zidovi su uklonjeni 1904. godine. ${ }^{40}$ Odzidavanje fontane počelo je krajem svibnja, što je popratio lokalni tisak: „Počelo se je ove sedmice sa radom o osamljenju Onofrijeve česme, te će sada onaj prostor izgledati ko da je progledao, a kog će resiti ona starinska česma, oko koje se do sada nije moglo hodati radi onog grdećeg zida koji je izgledao prolazniku ko pest u oči." ${ }^{\prime 1}$

38 BERITIĆ, „Dubrovački vodovod”, 110.

39 Stručna rasprava o vrijednosti Velike fontane i potrebi njezina očuvanja u fokus dolazi tek na prijelazu stoljeća. Više u: MAJER JURIŠIĆ, ŠURINA, Velika Onofrijeva fontana u Dubrovni$k u, 8$.

40 PIPLOVIĆ, „Javne gradnje u Dubrovniku za austrijske uprave”, 357-358; MAJER JURIŠIĆ, ŠURINA, Velika Onofrijeva fontana u Dubrovniku, 32-33, 35-38. O tom događaju javnost je pomno izvješćivana i na temelju napisa u Crvenoj Hrvatskoj. Tako se u veljači 1904. izvješćuje o natječaju za izvođenje radova na uklanjanju zidova: „Evo došlo je napokon vrijeme da se popravi i osami ona česma kod pilskih vrata. Već je otvoren natječaj za ponude. Sva radnja ima bit gotova kako čujemo do septembra t.g." (Crvena Hrvatska, 27. 2. 1904., 9). Krajem XIX. i početkom XX. stoljeća u gradu je podignuto još nekoliko fontana. Početkom 1898. planiralo se na Gundulićevu trgu postaviti fontanu koju bi izradio hrvatski kipar Ivan Rendić, a prikazivala bi temu iz Gundulićeve Dubravke. Sve troškove njezine izgradnje trebao je pokriti Antun Amerling. Međutim, ta je fontana podignuta na Brsaljama, a na Gundulićevu trgu 1902. napravljena je jedna manja. Fontana na Brsaljama postavljena je 1900. godine. Troškovi njezine izgradnje iznosili su 16.000 kruna, od čega su 5.417 kruna dali Antun Amerling i njegova dva brata, a ostatak troškova snosila je Općina. Godine 1901. podignuta je fontana u parku Gradac, čiju je izgradnju financirao austrougarski generalni poslanik u Buenos Airesu Niko Mihanović. Nacrt je izradio Baldo Kosić, a troškovi izgradnje iznosili su 10.000 kruna. Više u: PIPLOVIĆ, „Javne gradnje u Dubrovniku za austrijske uprave", 335.

${ }_{41}$ Crvena Hrvatska, 12. 3. 1904., 11, 2. 4. 1904., 14. Iako od polovine XX. stoljeća više nije imala ključno značenje u vodoopskrbi grada, Velika fontana danas je neprocjenjiv spomenik i svjedok gospodarskoga, društvenoga i kulturnoga dosega Dubrovnika u prošlosti. U kolovozu 1963. proglašena je zaštićenim spomenikom kulture, a 23. prosinca 1983. upisana je u Registar nepokretnih spomenika kulture (MAJER JURIŠIĆ, ŠURINA, Velika Onofrijeva fontana u Dubrovniku, 35, 38-39). 
Rekonstrukcije i održavanje vodovoda u prvoj polovini XX. stoljeća

Zbog porasta broja stanovnika na širem gradskom području ${ }^{42}$ te kontinuiranoga povećanja broja turističkih smještajnih kapaciteta i turističkih dolazaka nametnula se potreba izgradnje i širenja vodovodne mreže na područja Gruža i Lapada, gdje je porast i u broju stanovnika i u broju turističkih kapaciteta bio najizraženiji. ${ }^{43} \mathrm{O}$ širenju vodovodne mreže na tom području sredinom prosinca 1902. vijećalo je Općinsko vijeće i prihvatilo projekt zbog kojega je Općina uzela zajam od Luke Miloslavića u iznosu od 50.000 kruna s kamatom od 4,75\% godišnje na otplatni rok od 25 godina. ${ }^{44}$

Voda je bila poprilično skupa i za svaki potrošeni kubni metar plaćalo se 40 para. Voda se Općini plaćala na temelju potrošnje koju su pokazivali iznajmljeni vodomjeri. Godišnji iznos najma vodomjera određen je prema cijevnom promjeru protoka vode, a bilo ih je više vrsta - od 13, 20, 26, 30, 40 i $50 \mathrm{~mm}$. Za najmanji vodomjer od $13 \mathrm{~mm}$ godišnji najam iznosio je $10 \mathrm{kruna}$, a za najveći od $50 \mathrm{~mm} 40$ kruna. $^{45}$

Početkom XX. stoljeća sve više do izražaja dolaze problemi s dotrajalim vodovodnim kanalima i nedovoljnim ulaganjem u održavanje i obnovu gradskih fontana. Primjerice, u travnju 1903. u Crvenoj Hrvatskoj u rubrici „Gradska kronika” iznosi se sljedeća molba: „Pišu nam iz grada: Pošto smo se osvjedočili mnogo i mnogo puta da Ugledna Općina nastoji svim silama samo da koristi gradu i pučanstvu u svakoj prigodi i u svakom pogledu, s toga uhvamo da će i našoj želji nastojati da udovolji, netom uvidi da je opravdana i potrebna; naime: - najviša gradska česma kod Male Braće, taj drevni naš spomenik negda slobodnog Dubrovnika, u pokvarenom je stanju. Ima 10 točaka, a samo na 2 može da se toči, jer ostali točki pokvareni su od više godina, te na taj način narod mora da čeka po dulje vremena, dok svakog dogje red na točak, a istodobno u kutu kod zida neprestance voda ide u štetu - u more. S toga bi bilo veoma korisno da se popravi, koli za narod toli za poljepšanje grada. Ko

\footnotetext{
42 Tijekom XX. stoljeća stanovništvo gradskoga područja ubrzano raste. Prema podacima službene statistike, na području naselja Dubrovnik 1910. živjelo je 12683 stanovnika, 1961. godine 23 059, a već 1971. više od 30000 stanovnika (31 182). Vidi: KORENČIĆ, Naselja i stanovništvo SR Hrvatske, 219.

43 Godine 1896. bilo je 1676 turista, 1903. godine 11 424, a već 1912. godine 26030 . Više u: PERIĆ, Razvitak turizma u Dubrovniku i okolici, 64, 67-68, 78, 126, 150, 215 (bilj. 175). Krajem XIX. stoljeća i opatijska rivijera postaje austrijsko mondeno lječilište i važno turističko odredište. Takav razvoj povećao je potrebu za vodnim kapacitetima i zahtijevao je poboljšanje u vodoopskrbi, pa se već 1884. pristupilo poboljšanju vodoopskrbe i izgradnji vodovodne infrastrukture. Cjevovod koji je tada položen koristio se čak 100 godina, sve do rekonstrukcije vodovodnoga sustava Opatije polovinom osamdesetih godina XX. stoljeća. Više u: KOSTELAC, „Povijest vodovoda i vodoopskrbe Liburnije”, 269-280.

44 PERIĆ, Razvitak turizma u Dubrovniku i okolici, 78.

45 PERIĆ, Razvitak turizma u Dubrovniku i okolici, 78.
} 
što se Ugl. Općina neprestance skrbi za svako gradski dobrobit, s toga uhvamo da će se i za ovo pobrinut." ${ }^{36}$

Početkom stoljeća velikih problema s vodoopskrbom imali su stanovnici na gradskom području pod imenom Sveta Marija, koji su se vodom opskrbljivali na fontani Mrtvo zvono, i u tiskovinama se redovito javljaju informacije o prestanku dotoka vode do tamošnje fontane. Tako je u veljači 1904. u Crvenoj Hrvatskoj objavljeno: „Više puta do sad stanovnici ispod Svete Marije tužili su se da im svaki čas ponestaje vode na česmi u mrtvom zvonu. Prije se je mislilo, da se to dogagjalo radi nestašice vode, ali zaista sad ima dosta vode, isti se je slučaj ponovio nazad par dana. Pošto vodovod do u česmu na 'mrtvom zvonu' prolazi kroz vojarnu ispod Sv. Marije nekoji drže da vojnici Reg. Lacy zabavljaju se vodom, puštaju, zaustavljaju i čine tako da se dogje u nepriliku, jer jadna čeljad prisiljeni su hoditi po vodu do pred 'Malu Braću'. Interesirani mole s toga c. k. vojničku vlast da providi shodno." ${ }^{\prime 7} \mathrm{O}$ istom problemu ponovno se izvješćuje u svibnju 1904.: „Tuže nam se na 'Mrtvom zvonu' ispod Svete Marije da nemaju vode, te su za to prisiljeni da idu na 'Lužu' i drugovdje. Do koga je neka providi." ${ }^{48} \mathrm{Da}$ su problem opskrbe vodom predjela Svete Marije zaista uzrokovali vojnici potvrđuje se već u srpnju iste godine, kada je objavljeno: „Usprkos svim nastojanjima i zabranama vojnicima da ne diraju, ipak češće nema vode. Vojnici navraćaju vodu u svoju kasarnu 'pod Sv. Marijom', a jadna čeljad moraju da idu na 'Lužu' i pred Malu Braću po vodu." 49

Tijekom 1908. tisak izvještava da opet vlada nestašica vode u gradu: „Ima 7-8 dana, da je u gradu ponestalo pitke vode. Uzrok je što poduzetnik za opskrbu grada vodom, dava manje vode nego što je pogodbom obvezan." ${ }^{\circ 0} \mathrm{Za}$ nekoliko dana uslijedila je reakcija na prethodni novinski napis: „Pošto se u javnoj štampi iznese stvari neistinite, to očitom namjerom da se zavede stranputice javno mnenje, iza kako smo se raspitali na nadležnom mjestu, u stanju smo, da iznesemo slijedeće podatke: Voda, koju poduzetnik sa izvora u Rijeci dava u općinski vodovod, prima se na vodovodu po vodomjeru zakonito baždarenom, koji je još u početku, bio postavljen blizu vodovoda, dogovorno

\footnotetext{
46 Crvena Hrvatska, 4. 4. 1903., 14. Godine 1905. u tisku se ponovno kaže da izljevnici za vodu na Velikoj fontani nisu u funkciji: „Mnogi nam se tuže, da su na česmi iskvareni svi točci, tako da moraju slati po vodu na Pile, i plaćati za dvije male bročice po 3-4 nč. Moli se s toga Općinu, da bi tome doskočila, i to čim prije, jer je voda svakomu potrebna" (Prava Crvena Hrvatska / Dubrovnik/, 19. 8. 1905., 23). Godine 1906. nastavlja se s komentarima lošega održavanja Velike fontane: „Bilo bi dobro nabaviti par ovčica da popasu travu koja je prilično izrasla na Onofrijevoj česmi." Tek je sljedeće godine fontana cementirana iznutra jer je puštala vodu i postavljeni su novi izljevnici (MAJER JURIŠIĆ, ŠURINA, Velika Onofrijeva fontana u Dubrovniku, 38).

47 Crvena Hrvatska, 6. 2. 1904., 6.

48 Crvena Hrvatska, 28. 5. 1904., 22.

49 Crvena Hrvatska, 23. 7. 1904., 30.

50 Crvena Hrvatska, 23. 9. 1908., 71.
} 
između stranaka. Po ugovoru, poduzetnik je dužan davati dnevno u općinski vodovod $960 \mathrm{~m}^{3}$ vode, naime tu kolikoću ne samo sisati i tjerati prema vodovodu, već je sa vlastitim strojevima i konduktorom dotjerati i predati u općinski vodovod. Ne vrijede stoga razlozi, koliko je poduzetnik vode tjerao izvoru, već koliko je predao gori u vodovod. Toliko se kaže za bolje shvaćanje podataka koji slijede. Do dana 25 minulog augusta, grad je bio dovoljno opskrbljen vodom, a i vodomjer je redovito bilježio poprječno propisanu kolikoću [...]." U nastavku teksta donosi se izračun koliko je u 11 dana (od 25. kolovoza do 5. rujna), koliko su problemi trajali, u vodovod stiglo vode. Iznosi se da je trebalo biti isporučeno $10560 \mathrm{~m}^{3}$, a u vodovod je stiglo samo $7350 \mathrm{~m}^{3}$. Prema toj računici, u spomenutom razdoblju vodovodu je isporučeno $3210 \mathrm{~m}^{3}$ vode manje negoli je dogovoreno. Upravo je taj manjak prouzročio probleme i povremene nestašice. Na kraju teksta zaključuje se: „Po svemu tomu jasno je, da iznoseni računi stanovite osobe umjetno su sastavljeni u svrhu, da zavedu javnost."

Uvidjevši da nema jednostavnoga rješenja za probleme u vodoopskrbi, gradske se vlasti 1907. opet obraćaju stranim inženjerima u Beču. Iste godine pristigao je prijedlog za unapređenje vodovodne mreže od građevinske tvrtke inženjera G. Rumpele iz Beča, u kojem se predlaže napuštanje tlačenja vode $u$ stari vodovod uz pomoć hidrauličnih naprava u Rijeci i izrada posebne tlačne pumpe s dizelskim motorima. Pumpe i motori bili bi smješteni u posebnoj zgradi i više ne bi bili ovisni o mlinovima. Tlačne cijevi pumpe položile bi se kolnim putom do rezervoara koji bi se izgradio između Gruža i grada na nadmorskoj visini od $60 \mathrm{~m}$, a bio bi kapaciteta od 800 do $1000 \mathrm{~m}^{3}$. Iz toga rezervoara granale bi se cijevi za pojedine predjele, a sve kuće iznad rezervoara vodu bi i dalje crpile iz staroga vodovoda, koji bi se temeljito popravio. U mjesecima kad izvor Vrelo daje veće količine vode puštala bi se iz staroga vodovoda voda u novi rezervoar. Na taj način tijekom nekoliko mjeseci ne bi bilo potrebno tlačiti vodu iz Rijeke. ${ }^{52}$ Od predloženoga je 1907. izgrađen rezervoar Točilo kapaciteta $420 \mathrm{~m}^{3}$, a 1910. rezervoar Mlini kapaciteta $660 \mathrm{~m}^{3} .^{53}$

Idućih godina sve se više širi vodovodna mreža i postavljaju vodovodne cijevi prema privatnim objektima. Primjerice, cjevovod do Sv. Jakova dovršen je 1911., a bila su predviđena i tri nova ogranka: državnom cestom do Gruža,

51 Crvena Hrvatska, 9. 9. 1908., 73. Problemi i nestašice nastavili su se i idućih godina. Tako je 1909. popravljana odvodna cijev, pa neko vrijeme i u više navrata opet nije bilo vode, kao i u svibnju 1910. godine: „opet nema vode, naši 'vandali' opet su oštetili točke, i dok se ne poprave, trebalo je obustaviti vodu” (Crvena Hrvatska, 2. 10. 1909., 44, 28. 5. 1910., 43).

52 Sljedeće godine svoj prijedlog dostavilo je i građevinsko poduzeće Carl Schwartz iz Beča. Predlaže se pumpanje vode s izvora Rijeke u stari kanal uz pomoć motornih pumpi, i to 58 l/s, te izgradnja četiriju rezervoara: iznad Gruža, nad Kapelicom na Posatu, iznad Ploča, a četvrti, manji rezervoar, izgradio bi se za visoko položene predjele, a u njega bi se voda iz vodovoda tlačila uz pomoć automatske električne pumpe. Više u: BERITIĆ, „Dubrovački vodovod”, 111.

53 BERITIĆ, „Dubrovački vodovod”, 111. 
srednjim Konalom i uzduž željezničke obale u Gružu. Planirani trošak za te radove iznosio je 90.000 kruna. ${ }^{54}$ Budući da je iz godine u godinu sve više privatnih objekata bilo priključeno na vodovodnu mrežu, bilo je potrebno izraditi i pravilnik o pravima i ograničenjima njezina korištenja. Tako je na temelju zaključka Općinskoga vijeća 13. rujna 1912. odobren Pravilnik o uporabi vodovoda Općine dubrovačke, kojim su propisane različite opće i posebne odredbe za privatne korisnike vodovodne mreže. Prva stavka toga pravilnika kaže: „Niko ne može zakonito posjedovati ni dovesti vodu iz općinskog vodovoda, bez osobite dozvole koja se ima udijeliti na temelju ovog pravilnika. Proti onima koji bi doveli ili su već doveli vodu bez dopusta, Općina će po zakonu postupati." ${ }^{55}$ Osim općih i posebnih odredbi vezanih uz priključak i upotrebu vodovodne mreže, Pravilnikom su određene i vrste cijevi koje svi korisnici moraju uvesti u svoje privatne objekte. Primjerice, stavak 26. Pravilnika propisuje: „Cijevi moraju biti od željeza ili kositera obložene olovom, ili također od

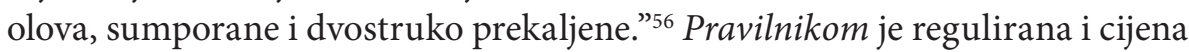
korištenja vodovodne infrastrukture te uvjeti pod kojima se može ograničiti ili čak ukinuti dotok vode do pojedinih objekata. ${ }^{57}$

Krajem 1913. posao širenja vodovodne mreže i rekonstrukcije vodovoda dobila je tvrtka inženjera Rumpele na temelju prijedloga iz 1907. godine. Nova generalna rekonstrukcija vodovoda sadržavala je 13 planova i nacrta prema kojima se tlačni vod promjera $375 \mathrm{~mm}$ trebao položiti trasom kolnoga puta Komolac (Rijeka) - Pile. Kod vrata od Pila vod bi se razdvajao u dva kraka, od kojih bi jedan ulazio u grad, a drugi bi išao do novoga rezervoara, koji je zamišljen na mjestu nižem od rezervoara Mlini. Kapacitet novoga rezervoara bio bi $1500 \mathrm{~m}^{3}$ i trebao je biti spojen s rezervoarom Mlini da bi se tijekom zimskih mjeseci grad opskrbljivao vodom iz staroga vodovoda, koji bi se temeljito obnovio. ${ }^{58}$ Prema nacrtu vodovodne mreže, unutar grada predviđen je jedan kružni vod promjera $200 \mathrm{~mm}$. Istoga promjera predviđena je i cijev duž Straduna, koja bi se na križanjima spajala s kružnim vodom. S tom cijevi i kružnim vodom spojile bi se cijevi promjera od 80 do $100 \mathrm{~mm}$ za sporedne ulice, na koje bi se priključivale pojedine zgrade. ${ }^{59}$ Prema tom posljednjem prijedlogu, dubrovački vodovod sastojao bi se od dva vodovodna kanala. Stari bi se popravio i na njega priključio izvor Bračevica i u njega bi se mogla tlačiti voda s izvora Rijeke. Drugi bi bio položen kolnim putom od izvora Rijeke do

\footnotetext{
PIPLOVIĆ, „Javne gradnje u Dubrovniku za austrijske uprave”, 334-335.

Pravilnik o uporabi vodovoda Općine dubrovačke, 1.

Pravilnik o uporabi vodovoda Općine dubrovačke, 6.

Više u: Pravilnik o uporabi vodovoda Općine dubrovačke, 5-6.

BERITIĆ, „Dubrovački vodovod”, 111-112.

BERITIĆ, „Dubrovački vodovod”, 112.
} 
grada i kroz njega bi se voda pumpama tlačila u veliki rezervoar blizu grada. Svaki od ta dva vodovoda mogao bi raditi i zasebno. ${ }^{60}$

Taj prijedlog za rekonstrukciju vodovoda Općina je početkom prosinca 1913. dostavila Kotarskom poglavarstvu, a ono Namjesništvu Dalmacije u Zadru s mišljenjem inženjera Kotarskoga poglavarstva Stjepana Wulpea. On se u konačnici ipak nije složio s predloženim jer je projekt iziskivao velike investicije i troškove. ${ }^{61}$ Wulpe je umjesto spomenutog predložio da se temeljito popravi vodovod od izvora Vrelo (Slavljana) do Nuncijate, gdje bi se sagradio rezervoar kapaciteta $1500 \mathrm{~m}^{3}$. Od rezervoara bi se provukle tlačne cijevi do grada kolnim putom. Za vrijeme ljetnih mjeseci, kad izvori Šumeta ne bi davali dostatne količine vode, voda bi se s izvora Rijeke tlačila u vodovod, a kapacitet tih pumpi morao bi biti $3000 \mathrm{~m}^{3}$ dnevno. ${ }^{62}$

Tijekom prve polovine 1914. inženjer Valerij Rieszner dostavio je novi tehnički elaborat o izgradnji dubrovačkoga vodovoda. U njemu predlaže iskorištavanje svih sedam izvora, koji su ukupno davali 85 litara vode u sekundi. Voda bi se iz visokih izvora usmjeravala u tunel duljine oko 1,5 km koji bi se probio od Šumeta do iznad Sv. Jakova, koji bi se iskoristio i kao rezervoar kapaciteta 4000-5000 $\mathrm{m}^{3}$. Kada izvori ne bi davali dostatno vode, voda bi se tlačila iz Rijeke u taj tunel. Od Sv. Jakova do Kantafiga glavne vodovodne cijevi protezale bi se kolnim putom. ${ }^{63} \mathrm{Nažalost,} \mathrm{ni} \mathrm{taj} \mathrm{prijedlog} \mathrm{nije} \mathrm{realiziran} \mathrm{jer} \mathrm{je}$ počeo Prvi svjetski rat i sve do 1920. za vodoopskrbu se i dalje koristio kanal staroga vodovoda. On je na nekoliko mjesta morao biti saniran zbog puknuća, što je smanjilo njegovu propusnost, a postojao je i rizik od zagađenja vode. ${ }^{64}$

Nakon Prvoga svjetskog rata izvedeno je nekoliko rekonstrukcija na vodovodnoj mreži. Od 1920. do 1922. napušten je dio staroga vodovoda od izvora Vrelo prema Šumetu u duljini od $1500 \mathrm{~m}$ i napravljen je tzv. šifon. To je bila cijev od lijevanoga željeza u koju se skupljala voda s izvora Vrelo. Cijev je (prema stanju iz 1950.) propuštala tek 38 1/s. Prilikom te rekonstrukcije napuštena su dva manja izvora, Vrijesna glavica i Marčevo. Od izvora Vrijesna glavica provedene su cijevi do sela Šumet, a selo Knežica priključeno je na izvorište Orahovac. Tadašnji je vodovod primao vodu samo s izvora Vrelo, Podvrelo i Bračevica. U spomenutom je razdoblju popravljena i dionica vodovodnoga

60 BERITIĆ, „Dubrovački vodovod”, 112.

61 HR-PVD, sv. 90, Prijedlog Općine dubrovačke br. 8401, 2. 12. 1913.; BERITIĆ, „Dubrovački vodovod", 112.

62 HR-PVD, sv. 90, Tehnički izvještaj inženjera Wulpea, 22. 12. 1913.; BERITIĆ, „Dubrovački vodovod", 112.

63 HR-PVD, sv. 90, Tehnički izvještaj i Generalna osnova za izgradnju Dubrovačkog vodovoda od inž. Valerija Reisnera; BERITIĆ, „Dubrovački vodovod”, 113.

64 MARIĆ, Projektno tehnička dokumentacija, 18. 
kanala od Daničić mosta (iznad Sustjepana) do Nuncijate, ali je propuštala samo 74 1/s. Tada je izgrađen i rezervoar Nuncijata. ${ }^{65}$

Da spomenute rekonstrukcije nisu poboljšale stanje u vodoopskrbi svjedoči molba od 26. rujna 1922. koju je uprava Općine Dubrovnik uputila Ministarstvu poljoprivrede. Molbom se od Ministarstva traži potpora i pomoć u rješavanju za Dubrovnik tada gorućega komunalnog problema. Među ostalim, tražilo se hitno izdavanje koncesije Općini za korištenje izvora Omble. Tražila se i financijska pomoć u obliku državnih subvencija, jamstva za zajam, ali i da državne institucije za nekoliko godina unaprijed plate pristojbe za potrošnju vode u državnim objektima. Na taj način namjeravala su se osigurati financijska sredstva za početak rada na projektu rekonstrukcije vodovoda. ${ }^{66}$

Radovima na vodovodnoj mreži od 1922. do 1926. izvedeni su prvi veći zahvati na rekonstrukciji trase staroga dubrovačkog vodovoda od njegove izgradnje. Projektom su predviđene tri glavne grupe radova. Prva grupa odnosila se na preuređenje izvorišta u Šumetu i adaptaciju glavnoga kanala te povećanje rezervoara za Dubrovnik i predgrađe s $1500 \mathrm{~m}^{3}$ na $4500 \mathrm{~m}^{3}$ po rezervoaru. Druga intervencija na vodovodu odnosila se na uvođenje jačih pumpi na izvor Omble, a treća na preuređenje gradske vodovodne mreže. Taj projekt služio je kao podloga za radove koji su se izvodili sve do četrdesetih godina XX. stoljeća. ${ }^{67}$

Godine 1927. donesena je još jedna vrlo važna odluka u pitanju opskrbe grada vodom. Prekinut je ugovor s vlasnikom mlinova na Ombli i o trošku Općine izgrađena je pumpna stanica s dvije pumpe. Postavljen je i novi tlačni vod od pumpe do staroga vodovoda promjera $300 \mathrm{~mm}$. Duljina toga cjevovoda bila je 1450 metara. ${ }^{68}$ Iste godine inženjer Sabo Jelić izradio je Tehničko-privredni izvještaj o komunalnim investicijama, u kojemu je za poboljšanje vodovoda imao nekoliko prijedloga. On se zalagao za varijantu prema kojoj bi se tlačni vod, koji bi opskrbljivao stanovništvo i punio rezervoar, položio kolnim putom. ${ }^{69}$

\footnotetext{
65 BERITIĆ, „Dubrovački vodovod”, 113-114.

66 HR-PVD, sv. 90. Koliko se godišnje trošilo na održavanje i troškove vodovoda saznaje se na temelju proračuna Općine iz 1923., koji je prikazan u dubrovačkom tjedniku Narodna svijest. Navodi se iznos od 519.262,64 dinara uz komentar: „Ovo je doista zamjerna svota, kojom je naša općina mogla nešto više nego uzdržavati vodovod u godini 1923. [...] gdje se silne pare na vodovod troše, a da vodom i u zimi oskudjevamo" (Narodna svijest, 10. 12. 1924., 51).

67 MARIĆ, Projektno tehnička dokumentacija, 40-41.

68 BERITIĆ, „Dubrovački vodovod”, 114.

69 HR-PVD, sv. 90, Tehničko-privredni ekspozej o komunalnim investicijama grada Dubrovnika od ing. Saba Jelića; BERITIĆ, „Dubrovački vodovod”, 114.
} 
Tijekom prve polovine XX. stoljeća intenzivira se razvoj turističke djelatnosti. ${ }^{70} \mathrm{U}$ Dubrovniku se već $1938 .{ }^{71}$ uvelike osjeća nedostatak vode i problem vodovodne infrastrukture u hotelskim smještajnim kapacitetima. Dubrovački vodovod tada je davao oko $960000 \mathrm{~m}^{3}$ vode na godišnjoj razini ili oko 2660 $\mathrm{m}^{3}$ vode dnevno. Prema izračunu, na svakoga potrošača otpadalo je oko 140 litara (19 000 potrošača) dnevno. Iako se ta količina vode smatrala dostatnom za opskrbu gradskoga stanovništva, problema u vodoopskrbi bilo je za vrijeme turističke sezone, kada se potrošnja povećavala. Najveći problemi tada su se javljali na višim predjelima Lapada i Ploča, gdje je ujedno bio i najveći broj hotela i pansiona. Dolazilo je do smanjenja pritiska vode u cijevima uslijed veće potrošnje u nižim zonama. ${ }^{72} \mathrm{Da}$ bi se to poboljšalo, trebalo je rekonstruirati vodovodnu mrežu. ${ }^{73}$ Stoga je već 1939. sastavljen novi projekt, koji je predviđao rekonstrukciju dovodnoga kanala na cjelokupnoj nerekonstruiranoj duljini od $9589 \mathrm{~m}$ s propusnom moći od 100 l/s. Predviđala se i gradnja novih rezervoara, čime bi se zapremnina povećala s dotadašnjih $1375 \mathrm{~m}^{3}$ na $6000 \mathrm{~m}^{3}$, te rekonstrukcija cjelokupne razvodne mreže cijevi. Međutim, realizaciju projekta obustavio je početak Drugoga svjetskog rata. Voda se tada preko noći morala zatvarati u svim predjelima, a upitna je postala i njezina zdravstvena ispravnost na starim i dotrajalim dionicama kanala na kojima su uslijed većih kiša u kanal prodirale nečistoće. ${ }^{74} \mathrm{O}$ tadašnjim problemima u vodoopskrbi svjedoči i novinski napis iz svibnja 1940. u tjedniku Narodna svijest. Tada je objavljen poziv svakom građaninu „[...] da uredi svoje gustijerne i da ih napuni vodom, jer bi ovog ljeta vodovod mogao izdati" ${ }^{75}$

\footnotetext{
70 Utjecaj turizma na povećane potrebe za vodom ne ogleda se samo u sezonskom povećanju broja turista. Naime, turisti osim primarne potrošnje vode (piće, kupanje, sanitarna voda) potiču i sekundarnu potrošnju, pa se potrošnja vode povećava i u drugim djelatnostima povezanima s turizmom i može se reći da se potrošnja vode potrebne za razvoj turističke djelatnosti povećava eksponencijalno s povećanjem smještajnih kapaciteta (SLAVUJ, ČANJEVAC, OPAČIĆ, „Vodoopskrba kao faktor održivog razvoja turizma otoka Krka”, 23-41).

71 Godina 1938. bila je rekordna po turističkim dolascima. U Dubrovniku je tada zabilježeno 58050 turista. Već sljedeće godine broj turista opada zbog najave i početka Drugoga svjetskog rada. Više u: KOBAŠIĆ, „Turizam u razvoju dubrovačkog gospodarstva”, 101; LUCIANOVIĆ, Povijest dubrovačkog hotelijerstva, 41.

72 Novine su redovito pratile i izvješćivale o izgradnji i širenju vodovodne mreže prema privatnim objektima. Primjerice, u Narodnoj svijesti piše: „Prošle sedmice počeo se je graditi vodovod od kuće Matijević u Lapadu na raskrsnici putem prama Sv. Mihajlu. Vodovod će se produžiti do kuće Goić. Ovim se je izašlo u susret jednoj neophodnoj potrebi, jer će vodom biti opskrbljeni svi pensioni i kuće u blizini ovog vodovoda" (Narodna svijest, 22. 8. 1929., 34).

73 MARIĆ, Projektno tehnička dokumentacija, 40-41.

74 HR-PVD, sv. 90.

75 Narodna svijest, 22. 5. 1940., 21. U istom tekstu donosi se i popis javnih bunara na gradskom području te se bilježi: „[...] 1. kraj crkve sv. Josipa. 2. Na dnu kabožine ulice. 3. Na raskršću Hotela de la Ville i Poljane Gundulićeve. 4. Na Placi Kr. Tomislava pred dućanom g. Gjura Veramente. 5. Kod crkve sv. Spasa."
} 
Tijekom Drugoga svjetskog rata (u vrijeme Nezavisne Države Hrvatske) bilo je dosta problema u opskrbi vodom. To potvrđuje Naredba Kotarskoga nadzorništva narodne zaštite u Dubrovniku iz 1943. prema kojoj je trebalo prijaviti Gradskom poglavarstvu bunare za vodu, navesti kolika im je zapremnina te je li voda u njima za piće. Primjerice, u kućama u vlasništvu Zbora popovskog u Dubrovniku bilježi se devet bunara na području grada, osam na području predgrađa Pile, jedan u predgrađu Ploče te još jedan u Lapadu. Bili su zapremnine od 18 do 127 kubika i u svima je bilo pitke vode. ${ }^{76}$

Godine 1941. izrađena je osnova za preuređenje vodovoda prema kojoj je cijeli vodovod trebalo rekonstruirati tako da od šifona do tlačne cijevi iz Rijeke može prolaziti voda kapaciteta 74 1/s. Od tlačne cijevi iz Rijeke do Daničić mosta, kao i od Nuncijate do rezervoara Točilo, promjer cjevovoda morao je biti 102 1/s. Od Točila do Mlina cjevovod je trebao biti kapaciteta 74 1/s. ${ }^{77}$ Vodovod je rekonstruiran i pojačan i 1945. godine. Tada je proširen vodovodni kanal od tlačne cijevi iz Rijeke do Daničić mosta, i to kapaciteta 102 1/s. Rekonstrukcija dionice vodovoda i povećanje cjevovodnoga kapaciteta na 102 1/s za dionicu od Nuncijate do rezervoara Točilo izvedena je 1947./48., a od šifona do tlačne cijevi iz Rijeke 1953. i otad je propuštala 85 l/s. Od 1953. do 1954. osposobljen je i uređen stari i napušteni izvor Bota, koji je nakon uređenja davao dvostruku količinu vode. On nije spojen na izvor Vrelo, nego se s njega vodom opskrbljivalo selo Komolac i nova klaonica. ${ }^{78}$

Rekonstrukcije vodovoda u drugoj polovini XX. stoljeća i izgradnja suvremenoga dubrovačkoga vodovodnog sustava

Prema „Izvješću o radu” za 1953. koje je upravitelj gradskoga vodovoda Frano Haler podnio Narodnom odboru grada, Savjetu za komunalne poslove, saznaje se što su sve obuhvaćali redoviti poslovi „Gradskoga vodovoda”: pumpanje vode iz izvora Omble u Komolcu, čuvanje i održavanje visokoležećih izvora u Šumetu s obodnim kanalom duljine 10426 m, održavanje tlačnoga cjevovoda duljine $1416 \mathrm{~m}$ te razvodne mreže duljine oko $20 \mathrm{~km}$ kao i svih rezervoara, davanje novih priključaka s eventualnom montažom vodomjera, održavanje, popravci i ispitivanje vodomjera, kontrola, obračun i naplata utro-

\footnotetext{
76 S druge strane, od devet bunara u kućama u vlasništvu Javne dobrotvornosti u samo dva nalazila se pitka voda, a ostali su kvalificirani ili kao šuplji, bez vode, ili je voda iz njih bila pogodna samo za pranje. Od osam bunara u vlasništvu Blagoga djela šest je imalo pitku vodu. Šest od osam bunara u vlasništvu Pravoslavne crkve imalo je pitku vodu. Prema sačuvanoj dokumentaciji u arhivi „Vodovoda Dubrovnik”, tada su ukupno prijavljena 54 bunara. Preuzeto iz: HR-PVD, sv. 84.

77 BERITIĆ, „Dubrovački vodovod”, 114.

78 BERITIĆ, „Dubrovački vodovod”, 115.
} 
šene vode. ${ }^{79}$ „Izvješće” također potvrđuje da je 1953. postavljena nova pumpa, koja je poboljšala vodoopskrbu grada tijekom ljetnih mjeseci i „po prvi put su ovog ljeta važni turistički objekti u Lapadu i na Pločama imali vode neprekidno kroz 24 sata. Dakle, u izvanredno sušnoj godini s uspjehom je izvršen zadatak i pokazao se znatni napredak u usporedbi s prošlim godinama" ${ }^{80}$

Potrošnja vode na području grada prikazana je u „Tehničkom izvještaju o stanju Gradskog vodovoda Dubrovnik”, koji je sastavio inženjer Ivo Miljević 1953. godine. Godišnji utrošak vode tada je iznosio $1400000 \mathrm{~m}^{3}\left(120000 \mathrm{~m}^{3}\right.$ na mjesečnoj razini). Posebno se za siječanj 1953. donosi detaljan utrošak vode i procjena nenaplaćenih gubitaka. Tako se u siječnju 1953. ukupno isporučilo $90000 \mathrm{~m}^{3}$ vode. Od toga je naplaćeno tek $47500 \mathrm{~m}^{3}$ ili $53 \%$. Gubici se očituju u nekoliko segmenata. Gubitak na mreži uslijed nepreciznosti vodomjera kod curenja iznosio je $20000 \mathrm{~m}^{3}$ (oko $22 \%$ ), gubitak uslijed pomanjkanja vodomjera $2500 \mathrm{~m}^{3}$ (oko $2,8 \%$ ), potrošnja sela koja se nije naplaćivala, a iznosila je oko $300 \mathrm{~m}^{3}$ dnevno ili $10000 \mathrm{~m}^{3}$ mjesečno (11\%), te potrošnja gradskih fontana, koja je iznosila oko $10000 \mathrm{~m}^{3}(11 \%){ }^{81}$

Iz „Izvještaja” komisije za pitanja opskrbe vodom iz prosinca 1955. saznaje se stanje u vodoopskrbi i mnogi problemi koje je bilo potrebno riješiti. Ističe se da se gradsko područje napaja vodom iz visokoležećih izvora u Šumetu is izvora Omble, odakle se uz pomoć triju električnih pumpi kapaciteta od 20, 35 i $90 \mathrm{l} / \mathrm{s}$ voda pumpa prema gradu. Tlačnim vodom dužine $1500 \mathrm{~m}$ i promjera $300 \mathrm{~mm}$ pumpe tjeraju vodu u gravitacijski kanal na visini od $104 \mathrm{~m}$. Gravitacijski kanal s padom od $0,6 \%$ od visokoležećih izvora do rezervoara Točilo etapno je renoviran, ali njegova propusna moć nije jednaka na svim dionicama. Rekonstruirani dio kanala (od 5870 do 7135 m) ima propusnu moć od 74 1/s, a na ostalim je dijelovima ona 102 l/s. Od rezervoara Točilo do rezervoara Mlini kanal se nalazi na pješačkom putu i kišnica ulazi u kanal, pa je na tom dijelu moguće zagađenje vode. Voda se zato jače klorirala. Voda se sabirala u četiri glavna rezervoara: rezervoar Gruž kapaciteta $110 \mathrm{~m}^{3}$, rezervoar Točilo kapaciteta $420 \mathrm{~m}^{3}$, rezervoar Vranac kapaciteta $110 \mathrm{~m}^{3}$ i rezervoar Mlini kapaciteta $660 \mathrm{~m}^{3}$. Preko rezervoara Gruž vodom se opskrbljivao predio od željezničke ložione do obale Radić; preko rezervoara Točilo od obale Radić do Doma narodnoga zdravlja, uključujući cijeli poluotok Lapad; preko rezervoara Vranac predio od Doma narodnoga zdravlja do Pila; preko rezervoara Mlini predio od Pila do Sv. Jakova. ${ }^{82}$

\footnotetext{
79 HR-PVD, sv. 81.

80 HR-PVD, sv. 81.

81 HR-PVD, sv. 81.

82 HR-PVD, sv. 81.
} 
Šezdesetih godina XX. stoljeća javljaju se novi problemi u vodoopskrbi. Kao jedan od većih ističe se napajanje pumpi električnom energijom jer je često dolazilo do nestanka struje, najčešće pod utjecajem vremenskih neprilika. Kao vodeći problem ističu se i nedostatni kapaciteti rezervoara s obzirom na to da se uvelike povećala potrošnja vode. Primjerice, 1947. potrošnja vode iznosila je $342000 \mathrm{~m}^{3}$, a u 1955. povećana je na $1100000 \mathrm{~m}^{3}$, što je povećanje za $321 \%$. To je u prosjeku oko $150 \mathrm{l}$ dnevno po stanovniku (20 000 stanovni$\mathrm{ka}){ }^{83}$ a kad se tome dodaju potrebe turističke djelatnosti ${ }^{84}$ i dnevne potrebe prekooceanskih brodova, koji su ponekad potraživali i više od $300 \mathrm{~m}^{3}$, uočljivo je da je poboljšanje vodoopskrbe postalo nužno. Na sve spomenuto nadovezuje se i problem gubitka vode zbog dotrajaloga i na nekim mjestima urušenoga vodovodnoga kanala te sve veći broj privatnih i turističkih objekata koji su se priključivali na vodovodnu mrežu. ${ }^{85}$

U svibnju 1956. komunalnom poduzeću „Gradski vodovod” dostavljen je račun za izvedene radove na popravku vodovodnoga kanala (u duljini od 131 m) blizu vodospreme Točilo. Radove je obavilo građevinsko poduzeće „Graditelj Dubrovnik”, a prema konačnom troškovniku građevinskih radova investicija je stajala 362.481 dinar. Poznato je i da su radovi trajali oko dva mjeseca s obzirom na to da su dogovarani u ožujku, a račun za izvedene radove ispostavljen je krajem svibnja. ${ }^{86}$ Međutim, već u kolovozu 1956. godine Tehnički odjel „Gradskoga vodovoda” pod rukovodstvom Jakira Celestina shvatio je da ulaganje isključivo u sanaciju i manje rekonstrukcije postojećega vodovodnoga kanala ne donosi potrebne rezultate, nego bi trebalo proširiti dionicu gravitacijskoga kanala na kapacitet od 102 1/s, a tlačni cjevovod dovesti u takvo stanje da može propustiti toliku količinu vode. Također se ističe da je neophodno obnoviti gradsku vodovodnu mrežu. ${ }^{87}$

Godine 1958. dubrovački vodovod počinje dobivati današnji oblik, a ključna promjena u opskrbi grada vodom dogodila se 1964., kada je probijen i stavljen u funkciju tunel kroz brdo Srđ od Komolca do glavne vodospreme u

\footnotetext{
83 Da 150 l vode dnevno po stanovniku nije dostatno potvrđuje i procjena iz 1970. prema kojoj su gradovi s više od 10000 stanovnika trebali osigurati preko 400 l vode po stanovniku na dnevnoj bazi (SARTI, Živjeti u kući, 135).

84 Turizam je na cijelom priobalnom području Hrvatske, pa tako i na dubrovačkom, nakon Drugoga svjetskog rata postao glavna gospodarska djelatnost koja je osigurala ubrzani ekonomski napredak. U Dubrovniku je već 1950. boravilo 60304 turista. Taj se broj u idućem razdoblju ubrzano povećavao - 1965. u Dubrovniku je zabilježeno 182619 turista, a deset godina poslije gotovo 300000 (299 018). Osamdesetih godina broj posjetitelja i dalje je rastao te je sredinom toga desetljeća dosegnuo 450 000. Više u: LUCIANOVIĆ, Povijest dubrovačkog hotelijerstva, 116.

85 HR-PVD, sv. 81

86 HR-PVD, sv. 81

87 HR-PVD, sv. 81.
} 
Dubrovniku u današnjoj Ulici Andrije Hebranga. ${ }^{88}$ Projekt je predviđao cjelokupnu opskrbu grada iz izvora Omble. ${ }^{89}$ Tunel je spojio taložnicu Ombla iznad Komolca, mjesta s kojega se pumpa voda iz izvora Omble prema rezervoaru Niska zona u Šipčinama. Time je glavna opskrba grada vodom ostvarena kroz tunel, a stara trasa na dionici od Omble do grada izgubila je svoju prvotnu funkciju. ${ }^{90}$ Voda koja ulazi iz taložnice Sašilo u kanal ima i dalje neometan protok do taložnice Ombla (pored ulaza u tunel), gdje se izlijeva u okoliš. ${ }^{91}$

Izvedbeni radovi na tom opsežnom i zahtjevnom projektu bili su podijeljeni na etape i obuhvaćali su različite građevinske radove: uređenje vrelišta, izgradnju crpne stanice s trafostanicom i postavljanje elektrostrojarske opreme, postavljanje cijevnih vodova - crpnih i tlačnih, probijanje i izgradnju dovodnoga tunela kroz Srđ i izgradnju vodospreme Dubrovnik I. Troškovi izvedbe cijeloga investicijskog projekta iznosili su 343.661.795 dinara. Voda se za potrebe grada tim projektom u potpunosti trebala crpiti iz izvora Omble, i to $\mathrm{u}$ kapacitetu od 242 1/s, koliko je procijenjena dnevna potreba grada za vodom..$^{92}$

\footnotetext{
88 Idejni projekt suvremenoga dubrovačkoga vodovodnog sustava izradio je „Inženjerski projektni zavod - Grupa za vodogradnje” pod vodstvom inženjera Milana Šinkovca, a na temelju Rješenja Izvršnoga vijeća NR Hrvatske br. 4193 od 9. travnja 1958. godine (HR-PVD, Idejni projekt novog dovoda i objekata, sv. 4-9). U vrijeme izgradnje direktor „Gradskoga vodovoda” bio je Ivo Jerinić, a za nadzornika izgradnje tlačnoga cjevovoda i crpne stanice Upravni odbor tvrtke postavio je Celestina Jakira.

89 Izvor rijeke Omble jedan je od najizdašnijih izvora dinarskoga krša s kvalitetnom pitkom vodom. Sliv mu se većim dijelom nalazi na teritoriju Bosne i Hercegovine, a sam izvor lociran je u Hrvatskoj. Više u: BONACCI, FUMET, ŠAKIĆ-TROGRLIĆ, „Analiza vodnih resursa izvora Omble", 107-118.

90 Dio stare trase od Nuncijate prema gradu služi i danas za sekundarnu distribuciju vode u kućanstva. Voda iz izvora Vrelo šifonom dotječe do taložnice Sašilo, gdje se klorira i distribuira potrošačima u Šumetu i dijelu Komolca. Dio vode pumpa se iz taložnice prema crpnoj stanici Šumet, iz koje se tlačnim vodovima opskrbljuju potrošači dijela Šumeta koji se nalazi iznad kanala (JOVIĆ, „Stari dubrovački vodovod”, 21; MARIĆ, Projektno tehnička dokumentacija, 22).

91 Premda se radi o neznatnoj količini vode, tijekom napada na Dubrovnik 1991., kada su agresori prekinuli dovod vode tlačnim cjevovodom s izvora Omble, voda iz toga kanala bila je presudna za vodoopskrbu grada tijekom opsade. Naime, u noći 10./11. listopada 1991. djelatnici „Vodovoda Dubrovnik” prošli su kroz tunel te, izloženi riziku, prespojili vodu iz taložnice Ombla u kanal u tunelu. To je osiguralo punjenje rezervoara Niska zona i opskrbu grada vodom tijekom ratnih dana (prema kazivanju Zlatka Fabrisa, dugogodišnjega djelatnika gradske tvrtke „Vodovod Dubrovnik”). Vidi i: MARIĆ, Projektno tehnička dokumentacija, 22-23.

92 Prema procjeni, za potrebe stanovništva grada trebalo je osigurati $9000 \mathrm{~m}^{3}$ vode dnevno, za potrebe turističke djelatnosti $6000 \mathrm{~m}^{3}$, za stanovništvo sela $141 \mathrm{~m}^{3}$, za polijevanje parkova 150 $\mathrm{m}^{3}$, za potrebe vrtova i zelenila u gradu $1500 \mathrm{~m}^{3}$, za ugostiteljstvo $141 \mathrm{~m}^{3}$, za vojni garnizon 230 $\mathrm{m}^{3}$, za željeznicu $400 \mathrm{~m}^{3}$, državne i gradske institucije $400 \mathrm{~m}^{3}$, opskrbu brodova $150 \mathrm{~m}^{3}$, bolnicu $600 \mathrm{~m}^{3}$ i industriju $500 \mathrm{~m}^{3}$. To je ukupno iznosilo $19212 \mathrm{~m}^{3}$, na što su se zaračunali gubici od $8 \%\left(1543 \mathrm{~m}^{3}\right)$ te vlastita potrošnja vodovoda od $259 \mathrm{~m}^{3}(1,3 \%)$. U konačnici je za područje grada tada trebalo osigurati oko $21014 \mathrm{~m}^{3}$ vode dnevno ili 242 l/s. Više u: HR-PVD, Idejni projekt novog dovoda i objekata, sv. 4.
} 
Da bi se uredilo i zaštitilo izvorišno područje, projektom je predviđen niz zahtjevnih pripremnih radova. ${ }^{93}$ Prije nego što se započelo s gradnjom trebalo je ishoditi i lokacijsko rješenje za izgradnju tlačnoga cjevovoda u Komolcu. ${ }^{94}$ U obrazloženju Rješenja istaknuto je da je predmetna izgradnja u suglasnosti s općim uputama za izradu generalnoga urbanističkog plana grada Dubrovnika te je na osnovi toga riješena opskrba grada Dubrovnika dovodom vode s izvora rijeke Omble tlačnim cjevovodom do ulaza u tunel kroz Srđ. Također na temelju Rješenja potpisan je Ugovor o pravu služnosti između vlasnika i posjednika nekretnina s jedne strane i tvrtke „Gradski vodovod” iz Dubrovnika s druge strane. Tim su ugovorom vlasnici zemljišta pristali na postavljanje tlačnoga cjevovoda preko njihove zemlje, uz naknadu štete koja bi nastala na nasadima, sadnicama i ostalim kulturama. Potpisnika je bilo 28 i svi su pristali na ugovorom zadane uvjete. ${ }^{95}$

Prema projektu, crpna je stanica smještena u blizini samoga izvora da bi crpni vodovi bili što kraći. S druge strane, a s obzirom na terenske prilike i skučen prostor oko samoga vrela, trafostanica je sagrađena na određenoj udaljenosti od crpne stanice. U crpnoj stanici planirane su dvije crpke - jedna koja je u pogonu, a druga kao rezerva. ${ }^{96}$ Dovod vode od crpne stanice do glavne vodospreme u Dubrovniku izveden je kombinacijom tlačnoga cjevovoda i tunelskoga rova u kojem je smješten betonski gravitacijski kanal. Tlačni je cjevovod od lijevanih željeznih cijevi promjera $500 \mathrm{~mm}$. Duljina mu je 1450 $\mathrm{m}$, a završava u preljevnoj građevini smještenoj u tunelu kod ulaznoga dijela. Tunel se od ulaznoga do izlaznoga portala proteže u duljini od $2994 \mathrm{~m}$, visok je 2,3 m, a širok $1,8 \mathrm{~m}$. Takve su dimenzije omogućavale slobodan prolaz tu-

\footnotetext{
93 Najprije je trebalo glavnu cestu, koja se dotad nalazila tik uz izvor, izmjestiti 150 m nizvodno od vrelišta. Potom je predviđeno ograđivanje i pošumljavanje užega izvorišnog područja, ali i njegovo čišćenje da bi se ekološki očuvao sam izvor Omble. Osim toga trebalo je posjeći i povaditi korov trstike i stara stabla koja su se nalazila na tom području, otkupiti vrtove od vlasnika i cijelu obalu pravilno oblikovati nasipavanjem (HR-PVD, Idejni projekt novog dovoda i objekata, sv. 6).

94 Rješenje je 18. lipnja 1959. izdao Sekretarijat za komunalne poslove Narodnoga odbora općine Dubrovnik na temelju čl. 15. Osnovne uredbe o generalnom urbanističkom planu, čl. 89. Statuta općine Dubrovnik i čl. 207. Zakona o općem upravnom postupku (HR-PVD, neoznačeno).

95 HR-PVD, neoznačeno. Rješenjem je „Gradskom vodovodu” u Dubrovniku odobreno korištenje zemljišta, odnosno uža lokacija na katastarskim česticama broj: 204, 205/5, 206, 355, 356, $35 / 3,35 / 4,220 / 1,230 / 1,230 / 2$, 333/2, 344/2, 345, 346/1, 364, 405, 440/3, 440/4, 30, 31/2, 31/3, $56 / 2,56 / 3,219,18 / 1,205 / 4,205 / 6,362 / 2,346 / 3,363 / 1,363 / 2,238 / 1,235 / 2,353 / 1,29 / 3,51 / 1$, $52 / 5,33 / 4,346 / 2,52 / 6,1,3,4$, 5, 6, 17/2, 17/1, 17/6 u k.o. Komolac i 312/1, 312/2, 313, 314/1, $314 / 2$ u k.o. Rožat.

96 HR-PVD, Idejni projekt novog dovoda i objekata, sv. 4. Crpne stanice vodu mogu crpsti na visinu od $93 \mathrm{~m}$. Na mjestu gdje crpke pumpaju vodu nalazi se rezervoar zapreminskoga prostora od $5000 \mathrm{~m}^{3}$ u obliku slova L. Taj rezervoar ima dvije komore, od kojih svaka može zasebno funkcionirati (JOVIĆ, „Stari dubrovački vodovod”, 21).
} 
nelskim rovom zbog kontrole tunela i održavanja kanala. Tunel je obložen betonskom oblogom od $30 \mathrm{~cm}$ i podom debljine $20 \mathrm{~cm}$. Pad tunela je $1 \%{ }^{97}$ Na kraju kanala nalazi se trapezasti rezervoar u kojem se prikuplja voda te se $s$ toga mjesta voda distribucijskom magistralnom mrežom dovodi u pojedine objekte na gradskom području. ${ }^{98}$ Radovi na tlačnom vodovodu krajem 1959. i tijekom 1960. bili su u punom zamahu, a izvodilo ih je Građevinsko poduzeće „Tempo".99

Zbog konfiguracije terena vodoopskrba grada morala je biti podijeljena na dvije osnovne visinske zone - nisku i visoku. Usporedno s izgradnjom tunela građena je i ukopana vodosprema Niska zona zapremnine $5000 \mathrm{~m}^{3}$ na samom kraju tunela. Vodosprema Niska zona opskrbljuje potrošače do kote od $65 \mathrm{~m}$ nadmorske visine. S druge strane, viši gradski predjeli obuhvaćeni su vodoopskrbnim sustavom Visoka zona. Izgradnjom crpne stanice i vodospreme od $2000 \mathrm{~m}^{3}$ u brdu Srđ (iznad Magistrale) omogućila se opskrba potrošača na visinskim kotama i do $125 \mathrm{~m}$ nadmorske visine. Tim sustavom obuhvaćena su sva visoka gradska područja - od Ploča preko Gruža do Montovjerne i Lapada. Nakon izgradnje sustava Visoka zona pristupilo se izgradnji vodoopskrbnoga sustava Srđ za potrebe tvrđave Imperijal. Izgrađena je crpna stanica, tlačni cjevovod i vodosprema zapremnine $400 \mathrm{~m}^{3}$. Taj sustav crpi vodu iz vodospreme Visoka zona i tlačnim ju cjevovodima doprema do vodospreme u tvrđavi Imperijal na koti na 404 m nadmorske visine. ${ }^{100}$

Otkad je projekt „Vodovoda Dubrovnik” stavljen u funkciju i probijen tunel kroz Srđ, duljina glavnih cjevovoda koji dovode vodu do Dubrovnika smanjila se na otprilike $5 \mathrm{~km}$ (za razliku od početnih $12 \mathrm{~km}$ ). Tada je gotovo

\footnotetext{
97 HR-PVD, Idejni projekt novog dovoda i objekata, sv. 9. Iskop tunela i njegovo betoniranje istovremeno je teklo i na ulaznoj i na izlaznoj strani. Rok za dovršenje iskopa bio je 24 mjeseca, od čega su dva mjeseca trajali pripremni radovi, pa je tunel trebalo završiti u 22 mjeseca. Radovi su se odvijali u tri smjene, a svaka je smjena trebala učiniti 1,3 m iskopa, dakle 3,9 m dnevno. Ulazni i izlazni portali tunela zatvoreni su teškim željeznim vratima koja su s unutrašnje strane obložena finom mjedenom mrežom koja sprečava ulaz kukcima. Vodovodni kanal kroz tunel izgrađen je tako da kroz njega može teći dvostruko više od projektom predviđene količine vode. To se učinilo da u budućnosti, kada se poveća potreba za vodom u gradu, ne bi trebalo rekonstruirati kanal. Kanal je pokriven armiranobetonskim pločama (HR-PVD, Idejni projekt novog dovoda i objekata, sv. 4).

98 JOVIĆ, „Stari dubrovački vodovod”, 21.

99 Tijekom radova bilo je i nezadovoljnika, osobito među stanovništvom koje je na području oko kanala imalo poljoprivredna zemljišta i zbog njegove izgradnje trpjelo različite štete i gubitke. Zbog toga su od Uprave dubrovačkoga vodovoda zahtijevali odštetu. Prema Zapisniku koji je sastavljen 7. siječnja 1960., odšteta u ukupnom iznosu od 337.229 dinara isplaćena je onima kojima su tijekom kopanja kanala uništeni poljoprivredni nasadi (HR-PVD, neoznačeno).

100 Prema kazivanju Zlatka Fabrisa, dugogodišnjega djelatnika gradske tvrtke „Vodovod Dubrovnik".
} 
potpuno napuštena opskrba grada vodom preko gravitacijskoga kanala, od kojega je u funkciji ostao samo dio od izvora Šumet do Komolca. ${ }^{101}$

Vodoopskrba naselja Šumet, Komolac i Sustjepan sve do osamdesetih godina XX. stoljeća bila je iz gravitacijskoga kanala. Naselja od Rožata do Mokošice vodu su dobivala cijevima položenima kroz Rijeku - iz Komolca do Rožata i iz Sustjepana do Mokošice. Međutim, nakon izgradnje stambenoga naselja Nova Mokošica i višestrukoga povećanja potreba za vodom započelo se s izgradnjom novoga sustava vodoopskrbe Rijeke dubrovačke. Tada je na izvoru u Komolcu postavljena crpna stanica i novi tlačni cjevovod. Ispod tunela na koti od $75 \mathrm{~m}$ nadmorske visine izgrađena je vodosprema Komolac zapremnine $2000 \mathrm{~m}^{3}$, iz koje su se vodom napajali svi potrošači od Komolca do Mokošice. Za potrebe potrošača na višim kotama na području Mokošice postavljena je crpna stanica kojom se voda prepumpava u vodospremu Mokošica (zapremnine $2000 \mathrm{~m}^{3}$ ) iznad sela Gornje Obuljeno na koti od 130 m nadmorske visine. ${ }^{102}$

Krajem devedesetih godina XX. stoljeća postavljena je vodovodna mreža od tvrđave Imperijal do naselja Bosanka, čime je to naselje prvi put priključeno na javni vodovodni sustav. ${ }^{103}$ Godine 2005. pristupilo se izradi i vodoopskrbnoga sustava Pobrežje - Petrovo Selo - Osojnik. Time su potrošači s tih područja dobili mogućnost priključenja na javnu vodovodnu mrežu. Za potrebe sustava izgrađene su crpne stanice (Gornje Obuljeno i Pobrežje), vodospreme (Pobrežje i Osojnik) te tlačni i gravitacijski cjevovodi. ${ }^{104}$

Upravo se opisanim projektima, prvenstveno izgradnjom tunela te uspostavom sustava Visoka i Niska zona, odredio daljnji tijek razvoja opskrbe grada vodom i zadani su temelji suvremenom dubrovačkom vodoopskrbnom sustavu, koji se zasniva na korištenju kapaciteta izvora Omble u Komolcu, izvora koji se nalazi na koti od 1,35 do $2 \mathrm{~m}$, a voda se crpkama podiže do preljevne komore na koti od 81,31 m, odakle gravitacijom teče cjevovodom kroz tunel ispod Srđa u glavnu gradsku vodospremu. Iz toga sustava, koji je

\footnotetext{
101 Da je izgradnja suvremenoga vodoopskrbnog sustava uvelike pospješila i turizam kao glavnu gospodarsku djelatnost dubrovačkoga područja pokazuju i brojke o turističkim dolascima, koje zasigurno ne bi bile ostvarive s dotadašnjom infrastrukturom i načinom vodoopskrbe. Broj turista do izgradnje suvremenoga vodovodnog sustava 1964. bio je ispod razine od 100 000, a u idućih desetak godina više se nego udvostručio. Primjerice, već 1975. bilježi se gotovo 300000 turista. O broju turista više u: LUCIANOVIĆ, Povijest dubrovačkog hotelijerstva, 116.

102 Prema kazivanju Zlatka Fabrisa, dugogodišnjega djelatnika gradske tvrtke „Vodovod Dubrovnik".

103 Prema kazivanju Zlatka Fabrisa, dugogodišnjega djelatnika gradske tvrtke „Vodovod Dubrovnik".

104 Prema kazivanju Zlatka Fabrisa, dugogodišnjega djelatnika gradske tvrtke „Vodovod Dubrovnik".
} 
rekonstruiran 1979., osigurana je opskrba Dubrovnika te naselja Stara i Nova Mokošica, Lozica, Komolac, Čajkovići i Sustjepan. ${ }^{105}$

\section{Zaključak}

Opskrba pitkom vodom najvažniji je zadatak svake društveno odgovorne zajednice, a kvaliteta življenja, dosegnuta razina društvenoga standarda i razvoj određenih gospodarskih djelatnosti u izravnoj su vezi s kvalitetom vodoopskrbnoga sustava. Dubrovačka je vlada još u prvoj polovini XV. stoljeća unaprijedila svoju vodoopskrbu izgradnjom cjelovitoga vodovodnog sustava. Bio je to projekt koji je označio prekretnicu u društveno-gospodarskom napretku i svojom važnošću obilježio daljnji razvitak Dubrovnika, utjecao na poboljšanje kvalitete života u gradu, ali i potvrdio sposobnost tadašnje vlade da realizira tako skup i nadasve zahtjevan projekt. Njegova komunalna vrijednost očituje se i u činjenici da je tada izgrađen vodovodni kanal, uz nekoliko nadogradnji i preinaka, gradsko područje opskrbljivao vodom sve do sredine XX. stoljeća, kada se započelo s radovima na rekonstrukciji i izgradnji suvremenoga vodoopskrbnog sustava Dubrovnika.

Tijekom XIX. stoljeća zbog financijskih nemogućnosti popravljalo se samo nužno, a sve veća potreba za vodom rješavala se manjim rekonstrukcijama dotrajaloga vodovodnoga kanala i ojačavanjem već postojećega sustava, bez većih nadogradnji. No, kada se krajem XIX. stoljeća voda počela provoditi u pojedine institucije, a početkom XX. stoljeća i u privatne objekte, problem vodoopskrbe postaje sve izraženiji. Tada se nametnula potreba izgradnje novoga cjelovitoga vodoopskrbnog sustava koji bi se koristio vodnim bogatstvom izvora rijeke Omble, najizdašnijim izvorom dubrovačkoga područja. Prvi pokušaj poboljšanja vodoopskrbe realiziran je 1897., kada je s vlasnikom mlinova na izvoru Omble sklopljen ugovor da pomoću dvije tlačne pumpe u stari kanal isporučuje $960 \mathrm{~m}^{3}$ vode dnevno. Pogon tih pumpi bila je snaga vode, a način funkcioniranja sličan onom koji pokreće mlinove. No, vrlo brzo i takvo se rješenje pokazalo nedostatnim, pogotovo kada se početkom XX. stoljeća počelo raditi na širenju vodovodne mreže i postavljanju vodovodnih cijevi prema privatnim objektima na gradskom području.

Ključne promjene u opskrbi grada vodom zbivaju se nakon 1958., kada je izrađen projekt suvremenoga dubrovačkog vodovoda. Projekt je realiziran 1964., kada je probijen i stavljen u funkciju tunel kroz brdo Srđ. Tunelom se voda s izvora Omble pumpa prema rezervoarima te dalje prema objektima na

105 Prema podacima iz 2008., stanovništvo i gospodarstvo cijele Dubrovačko-neretvanske županije vodom se opskrbljuje iz deset neovisnih vodoopskrbnih sustava. Više u: TUŠAR, „Vodoopskrba u Dubrovniku", 54-59. 
gradskom području. Zbog konfiguracije terena vodoopskrba je morala biti podijeljena na dvije osnovne visinske zone - nisku i visoku. Vodosprema Niska zona opskrbljuje potrošače do kote od $65 \mathrm{~m}$ nadmorske visine, a viši gradski predjeli pokriveni su vodospremom Visoka zona. Tada je gotovo sasvim napuštena opskrba grada vodom preko gravitacijskoga kanala, od kojega je u funkciji (sve do osamdesetih godina XX. stoljeća) ostao samo dio od izvora Šumet do Komolca i Sustjepana.

Upravo se tim projektima, prvenstveno izgradnjom tunela te uspostavom sustava Visoka zona i Niska zona, odredio daljnji tijek razvoja opskrbe grada vodom, koji se temelji na korištenju izdašnoga izvora rijeke Omble u Komolcu.

\section{Arhivski izvori}

HR-DADU: Hrvatska, Državni arhiv u Dubrovniku:

- Acta Consilii Maioris, ser. 8.

- Acta Consilii Rogatorum, ser. 3.

- Acta Gallica, kut. 126.

- Diversa Cancellariae, ser. 25.

- Fabricae, ser. 7.

HR-PVD: Hrvatska, Pismohrana „Vodovod Dubrovnik”.

\section{Periodičke publikacije}

Crvena Hrvatska (Dubrovnik), 1897, 1903-1905, 1908-1910.

Prava Crvena Hrvatska (Dubrovnik), 1905.

Narodna svijest (Dubrovnik), 1924, 1929, 1940.

\section{Literatura}

AHMETOVIĆ, Suad. Dubrovački kurioziteti iz dva minula tisućljeća. Dubrovnik: Vlastita naklada, 2006.

APPENDINI, Francesco Maria. „Ratovanje oko Dubrovnika godine 1806”. Kolo: časopis Matice hrvatske. Dvjesto godina poslije (2008), br. 2. Pristup ostvaren 20. 8. 2019. http://www.matica.hr/kolo/310/ratovanje-oko-dubrovnika-godine-1806-20587/.

BAZALA, Vladimir. Pregled povijesti zdravstvene kulture Dubrovačke Republike. Zagreb: Dubrovački horizonti, 1972. 
BELAMARIĆ, Joško, ur. Dubrovnik sa starih razglednica. Pula; Dubrovnik; Split: ISC; Dubrovački muzeji; Državna uprava za zaštitu kulturne i prirodne baštine, Glavno povjerenstvo u Splitu, 1996.

BELAMARIĆ, Joško. „Fontane”. U: Dubrovnik sa starih razglednica, ur. Joško Belamarić. Dubrovnik: Dubrovački muzej; Državna uprava za zaštitu kulturne i prirodne baštine, 1996, 186.

BELAMARIĆ, Joško. „Urbanistički aspekti prve dubrovačke industrije u 15. stoljeću”. U: Zbornik Dana Cvita Fiskovića II - Renesansa i renesanse u umjetnosti Hrvatske, ur. Predrag Marković i Jasenka Gudelj. Zagreb: Institut za povijest umjetnosti, 2008, 341-372.

BERITIĆ, Lukša. „Dubrovački vodovod”. Anali Historijskog instituta JAZU u Dubrovniku 8-9 (1960-1961): 99-116.

BERITIĆ, Lukša. Urbanistički razvitak Dubrovnika. Zagreb: Zavod za arhitekturu i urbanizam Instituta za likovne umjetnosti JAZU, 1958.

BONACCI, Ognjen; FUMET, Manon; ŠAKIĆ-TROGRLIĆ, Robert. „Analiza vodnih resursa izvora Omble”. Hrvatske vode 22 (2014), br. 88: 107-118.

ČUČIĆ, Vesna. Posljednja kriza Dubrovačke Republike. Zagreb; Dubrovnik: Zavod za povijesne znanosti HAZU u Dubrovniku; Matica hrvatska, 2003.

ĆOSIĆ, Stjepan. Dubrovnik nakon pada Republike (1808. - 1848.). Dubrovnik: Zavod za povijesne znanosti HAZU u Dubrovniku, 1999.

DIVERSIS, Filip de. Opis slavnoga grada Dubrovnika. Predgovor, transkripcija i prijevod s latinskog Zdenka Janeković Römer. Zagreb: Dom i svijet, 2004.

FABIJANEC, Sabine Florence. „Uloga vode u svakodnevnom životu srednjovjekovne Hrvatske”. Gazophylacium: časopis za znanost, umjetnost, gospodarstvo i politiku 17 (2012), br. 1-2: 9-43.

FISKOVIĆ, Cvito. „Petar Martinov iz Milana i pojava renesanse u Dubrovniku”. Prilozi povijesti umjetnosti u Dalmaciji 27 (1988): 89-144.

FISKOVIĆ, Igor. Reljef renesansnog Dubrovnika. Dubrovnik: Matica hrvatska, Ogranak Dubrovnik, 1993.

GRUJIĆ, Nada. „Onofrio di Giordano della Cava i Knežev dvor u Dubrovniku”. U: Zbornik Dana Cvita Fiskovića II - Renesansa i renesanse u umjetnosti Hrvatske, ur. Predrag Marković i Jasenka Gudelj. Zagreb: Institut za povijest umjetnosti, 2008, 9-50.

HORVAT, Jasenko. „Fontana i njezino mjesto u kompozicijama gradskog prostora”. Prostor 2 (1994), br. 3-4: 341-350. 
IPŠIĆ, Irena; LAZAREVIĆ, Ivana. „Water in the urban space of Dubrovnik”. Povijesni prilozi 56 (2019): 181-198.

JANEKOVIĆ RÖMER, Zdenka. „Extension of the Ragusan aqueduct from the spring in Knežica, 1518-1520: common concern of the government and people for the common good”. U: Scripta in honorem Igor Fisković. Zbornik povodom sedamdesetog rodendana $=$ Festschrift in the occasion of his 70th birthday, ur. Miljenko Jurković i Predrag Marković. Zagreb; Motovun: University of Zagreb, Faculty of Humanities and Social Sciences; International Research Center for Late Antiquity and the Middle Ages, 2015, 319-326.

JEREMIĆ, Risto; TADIĆ, Jorjo. Prilozi za istoriju zdravstvene kulture starog Dubrovnika, sv. I. Beograd: Centralni higijenski zavod, 1938.

JEREMIĆ, Risto; TADIĆ, Jorjo. Prilozi za istoriju zdravstvene kulture starog Dubrovnika, sv. III. Beograd: Centralni higijenski zavod, 1940.

JOVIĆ, Damir. „Stari dubrovački vodovod”. Diplomski rad, Građevinski fakultet Sveučilišta u Zagrebu, 2008.

JURIĆ, Zlatko. „Arhitekt Martin Pilar - zagrebački radovi 1889-1900”. Radovi Instituta za povijest umjetnosti 18 (1994): 152-167.

KOBAŠIĆ, Antun. „Turizam u razvoju dubrovačkog gospodarstva tijekom 20. stoljeća”. Ekonomska misao i praksa 2 (1993), br. 2: 97-115.

KORENČIĆ, Mirko. Naselja i stanovništvo SR Hrvatske 1857-1971. Djela JAZU, knj. 54. Zagreb: JAZU, 1979.

KOSTELAC, Melinda. „Povijest vodovoda i vodoopskrbe Liburnije 1884. - 2009. (povodom 125. obljetnice gradnje prvog liburnijskog vodovoda) - 1 . dio". Hrvatske vode 17 (2009), br. 69/70: 269-280.

KRIVOŠIĆ, Stjepan. Stanovništvo Dubrovnika i demografske promjene u prošlosti. Dubrovnik: Zavod za povijesne znanosti JAZU u Dubrovniku, 1990.

LONZA, Nella. „Svakodnevica Kneževa dvora u Dubrovniku u XVIII. stoljeću”. Otium 2 (1994), br. 1-2: 3-17.

LUCIANOVIĆ, Lukša. Povijest dubrovačkog hotelijerstva (od prvih prenoćišta u Dubrovačkoj Republici do modernih pansiona i hotela uoči Domovinskog rata). Dubrovnik: Udruga za očuvanje tradicije dubrovačkog turizma „Dubrovački izlog”, 2014.

MAJER JURIŠIĆ, Krasanka; ŠURINA, Edita. Velika Onofrijeva fontana u Dubrovniku - povijesnoumjetnička i konzervatorska studija. Mala biblioteka Godišnjaka zaštite spomenika kulture Hrvatske, sv. 16. Zagreb: Ministarstvo kulture, Uprava za zaštitu kulturne baštine, 2016. 
MARIĆ, Mara. Projektno tehnička dokumentacija za obnovu trase dubrovačkog renesansnog vodovoda. Konzervatorski elaborat (predstudija obnove i potrebna ispitivanja). Dubrovnik: Trames Consultants d.o.o., 2015.

MIOVIĆ, Vesna. Židovski geto u Dubrovačkoj Republici (1546-1808). Zagreb; Dubrovnik: Hrvatska akademija znanosti i umjetnosti, Zavod za povijesne znanosti u Dubrovniku, 2005.

MUMFORD, Lewis. Grad u historiji. Njegov postanak, njegovo mijenjanje, njegovi izgledi. Prev. Vladimir Ivir. Zagreb: Naprijed, 1988.

NOVAK KLEMENČIČ, Renata. „Dubrovniška Velika fontana”. Zbornik za umetnosno zgodovino 39 (2003): 57-91.

PERIĆ, Ivo. „Organizacija i djelovanje pokrajinske bolnice u Dubrovniku od izgradnje njene nove zgrade do prvog svjetskog rata”. Anali Zavoda za povijesne znanosti Istraživačkog centra JAZU u Dubrovniku (1985), br. 22/23: 175-222.

PERIĆ, Ivo. „Organizacija zdravstvene službe i zdravstvene prilike u Dalmaciji potkraj 19. i početkom 20. stoljeća”. Rasprave i građa za povijest znanosti HAZU 7 (1992): 187-204.

PERIĆ, Ivo. Razvitak turizma u Dubrovniku i okolici od pojave parobrodarstva do 1941. godine. Dubrovnik: Zavod za povijesne znanosti IC JAZU u Dubrovniku, 1983.

PIPLOVIĆ, Stanko. „Javne gradnje u Dubrovniku za austrijske uprave”. Građa i prilozi za povijest Dalmacije 18 (2002): 315-392.

PIPLOVIĆ, Stanko. „Početak gradnje modernih bolnica u Dalmaciji”. Radovi Zavoda za povijesne znanosti HAZU u Zadru 43 (2001): 311-340.

Pravilnik o uporabi vodovoda Općine dubrovačke. Odobren zaključkom Općinskog Vijeća od 13. septembra 1912. Br. 5600. Dubrovnik: Štamparija de Giulli i dr., 1912.

RADOVIĆ MAHEČIĆ, Darja. „Sekvenca secesije - arhitekt Lav Kalda”. Radovi Instituta za povijest umjetnosti (2006), br. 30: 241-264.

ROLLER, Dragan. Dubrovački zanati u XV. i XVI. stoljeću. Građa za gospodarsku povijest Hrvatske, knj. 2, ur. Mijo Mirković. Zagreb: Jugoslavenska akademija znanosti i umjetnosti, 1951.

SARTI, Raffaella. Živjeti u kući: stanovanje, prehrana i odijevanje u novovjekovnoj Europi (1500. - 1800.). Zagreb: Ibis grafika, 2006.

SEFEROVIĆ, Relja. „Radovi na dubrovačkom vodovodu od velikog potresa 1667. godine do pada Dubrovačke Republike". Radovi Instituta za povijest umjetnosti (2016), br. 40: 141-154. 
SEFEROVIĆ, Relja; STOJAN, Mara. „Čudo vode: prolegomena za ranorenesansni vodovod u Dubrovniku”. Anali Zavoda za povijesne znanosti HAZU u Dubrovniku (2006), br. 44: 95-137.

SINDIK, Joško; BRIŠKI, Marijana. „Različitost percepcije simboličkog značenja vode”. Anali Zavoda za povijesne znanosti HAZU u Dubrovniku (2016), br. 54/2: 453-468

SLAVUJ, Lana; ČANJEVAC, Ivan; OPAČIĆ, Vuk Tvrtko. „Vodoopskrba kao faktor održivog razvoja turizma otoka Krka”. Hrvatski geografski glasnik 71 (2009), br. 2: 23-41.

STOJAN, Slavica. Vjerenice i nevjernice. Žene u svakodnevici Dubrovnika (1600-1815). Zagreb; Dubrovnik: Zavod za povijesne znanosti HAZU u Dubrovniku, 2003.

TUŠAR, Božena. „Vodoopskrba u Dubrovniku”. EGE (2008), br. 4: 54-59.

VITELLESCHI, Lorenzo. Povijesne i statističke bilješke o Dubrovačkom okrugu. Prikupio okružni inženjer Lorenzo Vitelleschi. Dubrovnik 1827. = Notizie storiche e statistiche del Circolo di Ragusa - compilate dall ingegnere circolare Lorenzo Vitelleschi - Ragusa MDCCCXXVII. Uvodnu studiju i bilješke napisao Vinicije B. Lupis. Dubrovnik: Matica hrvatska Dubrovnik; Državni arhiv u Dubrovniku, 2002.

VOJKOVIĆ, Goran; ŠTAMBUK-ŠUNJIĆ, Marija. „Dva hrvatska zakona o pravnom statusu voda: Zakon o vodnom pravu iz 1891. i Zakon o vodama iz 2009”. Pravni vjesnik 27 (2011), br. 2: 201-214.

VOJNOVIĆ, Lujo. Pad Dubrovnika (1797. - 1806.). Zagreb: Fortuna, 2009.

VUKOVIĆ, Goran. „Preobrazba Dubrovnika početkom 19. stoljeća”. Radovi Instituta za povijest umjetnosti (2000), br. 24: 35-60.

VUKOVIĆ, Goran. „Vode, zdenci i fontane dubrovačkog kraja. I. dio”. Hrvatska vodoprivreda 22 (2014), br. 209: 67-71.

VUKOVIĆ, Goran; ANDROVIĆ, Ante. „Vode, zdenci i fontane dubrovačkog kraja. II. dio". Hrvatska vodoprivreda 23 (2015), br. 211: 82-83.

ŽILE, Ivica. „Srednjovjekovna kanalizacija grada Dubrovnika”. Starohrvatska prosvjeta 3 (2007), br. 34: 437-449. 


\section{SUMMARY}

\section{The Waterworks in Dubrovnik in the $19^{\text {th }}$ and $20^{\text {th }}$ Centuries}

Based on existing knowledge, archival documents, old newspaper articles, and documentation from the contemporary city company 'Vodovod Dubrovnik' (Dubrovnik Waterworks), this paper follows the development of the Dubrovnik waterworks during the $19^{\text {th }}$ and $20^{\text {th }}$ centuries. The backbone of the new waterworks until the mid- $20^{\text {th }}$ century was the gravity flow water distribution system built in the $15^{\text {th }}$ century. This was an important project that signified a turning point in socio-economic progress and left a significant mark on the further development of Dubrovnik. Its communal value is also apparent from the fact that a water canal was built at that time and, with several extensions and modifications, continued to provide water to the city area until the mid- $20^{\text {th }}$ century, when construction of the contemporary Dubrovnik water supply system began. Due to financial difficulties, repair work was limited to the most critical issues, while the increasing demand for water was met by smaller-scale reconstructions of the aging water canal and reinforcing the existing gravity flow system. However, with the increase in the urban population in the late 19th century and the introduction of water into certain institutions and private objects, supplying water became increasingly problematic and the necessity of building a new, complete water supply system increasingly apparent. The first attempt to improve the water supply took place in 1897 , when a contract was made with the owner of the mills at the spring of the river Ombla, the most abundant source of potable water in this area, to transmit a certain amount of water to the old water canal. However, this solution soon proved inadequate, and the issue of supplying water remained unresolved until 1964, when the project of the contemporary Dubrovnik water supply system was realised and a tunnel through the Srd hill was built, allowing water from the Ombla river spring to be pumped with electric pumps to newly built reservoirs and objects in the city area. The gravity canal was then almost completely abandoned, leaving only the part from the Šumet spring to Komolac and Sustjepan active (until the 1980s).

Key words: Dubrovnik; waterworks; gravity canal; fountain; $19^{\text {th }}$ and $20^{\text {th }}$ centuries 